Supporting Information for

\title{
Design, Synthesis, and Application of a Small Molecular NIR-II Fluorophore with Maximal Emission Beyond 1200 nm
}

Yu Fang, ${ }^{\text {ab }}$ Jizhen Shang, ${ }^{\text {a }}$ Diankai Liu, ${ }^{a}$ Wen Shi,${ }^{\text {ab } *}$ Xiaohua Li,${ }^{a}$ Huimin Ma ${ }^{a b *}$

${ }^{a}$ Beijing National Laboratory for Molecular Sciences, Key Laboratory of Analytical Chemistry for Living Biosystems, Institute of Chemistry, Chinese Academy of Sciences, Beijing 100190, China. E-mail: mahm@iccas.ac.cn; shiwen@iccas.ac.cn.

${ }^{\mathrm{b}}$ University of Chinese Academy of Sciences, Beijing 100049, China. 


\section{Experimental Section}

Materials and reagents. 4,7-Dibromo-2,1,3-benzothiadiazole was purchased from Ark Pharm, Inc. $\mathrm{SeO}_{2}$ was obtained from J\&K Scientific Ltd. Trifluoroacetic acid (TFA) and O-benzotriazole-N,N,N',N'-tetramethyl-uronium-hexafluorophosphat (HBTU) were purchased from InnoChem Science \& Technology Co., 3-(4,5-Dimethyl-2thiazolyl)-2,5-diphenyl-2H-tetrazolium bromide (MTT) and Dulbecco's modified Eagle's medium (DMEM), trypsin-EDTA digestive juice, and pH 7.4 phosphate buffer saline (PBS) were purchased from KeyGEN Bio TECH Co., Ltd. Fetal bovine serum (FBS) was obtained from Invitrogen Corporation. Albumin from bovine serum and indocyanine green (ICG) were purchased from Sigma-Aldrich. 9,9-Bis[2-(trimethylsilyl)ethyl]ester was purchased from Jiangsu GR-Chem Biotech Co., Ltd. 1,2-Distearoyl-sn-glycero-3-phosphoethanolamine-N-[methoxy(PEG)-5000] (DSPE-mPEG ${ }_{5000}$ ) was obtained from Corden Pharma. Ultrapure water (over 18 $\mathrm{M} \Omega \cdot \mathrm{cm}$ ) from a Milli-Q reference system (Millipore) was employed throughout. The stock solution of CF1065 or FM1210 was prepared with DMSO. The stock solutions of FM1210-NPs were prepared with PBS.

Apparatus. ${ }^{1} \mathrm{H}-\mathrm{NMR}$ and ${ }^{13} \mathrm{C}-\mathrm{NMR}$ spectra were performed on Fourier 300 or 400 (Bruker). High-resolution matrix-assisted laser desorption ionization mass spectra (HR-MALDI-MS) were performed on APEX IV FTMS (Bruker). Transmission electron microscopy image was taken from a JEM-2010 (Hitachi). UV-vis absorption spectra were made by a UV-2600 (Shimadzu) spectrometer with a integrating-sphere accessory in 1-cm quartz cells. Fluorescence spectra were measured on NIRQuest-512 spectrofluorimeter (Ocean Optics) in $1 \times 1 \mathrm{~cm}$ quartz cells. High-performance liquid chromatography (HPLC) analyses were conducted on LC-20AT and SPD-20A (Shimadzu) with Ultimate XB-C18 column $(5 \mu \mathrm{m}, 4.6 \mathrm{~mm} \times 250 \mathrm{~mm}$, Welch Materials, Inc.). The absorbance measurements in MTT analysis were measured on I3 microplate reader (Molecular Device). Dynamic light scattering was measured on Zetasizer Nano ZS ZEN3600 (Malvern Instruments Ltd.). In vivo fluorescence imaging was carried out with the In Vivo NIR-II imaging system (In Vivo Master, Wuhan Grand-imaging Technology Co., LTD) equipped with an InGaAs camera C-RED2 (Firstlight). Unless otherwise noted, the images with FM1210 and FM1210-NPs were excited with $980 \mathrm{~nm}$ and the emissions were collected with a 1150-nm longpass filter (Edmund Optics, Barrington, New Jersey); the images with CF1065 or ICG were excited with $808 \mathrm{~nm}$ and the emissions were collected with a 1000-nm longpass filter (Edmund Optics, 
Barrington, New Jersey). The 1300-nm longpass filter (Edmund Optics, Barrington, New Jersey) was also used occasionally. The excitation intensity of $808 \mathrm{~nm}$ or $980 \mathrm{~nm}$ laser (Wuhan Grand-imaging Technology Co., LTD) was $80 \mathrm{~mW} / \mathrm{cm}^{2}$, and the exposure time (ET) of images was indicated in the related figure legends. The time point after injection of fluorescent substances (FM1210, CF1065, ICG, or FM1210-NPs) was noted on the corresponding in vivo images. The relative pixel intensity values of all the related images were labeled in a nearby pseudo-color strip.

Synthesis and characterization of FM1210. Compound 1, compound 2 and CF1065 were synthesized according to the previous literature. ${ }^{1}$ Under $\mathrm{N}_{2}$ atmosphere, compound 1 (275 mg, $0.2 \mathrm{mmol}$ ) and $\mathrm{SeO}_{2}(56 \mathrm{mg}, 0.5 \mathrm{mmol})$ were refluxed in THF for $40 \mathrm{~min}$. Then the solvent was removed under reduced pressure. The residue was subjected to silica-gel column chromatography with $\mathrm{CH}_{2} \mathrm{Cl}_{2} / \mathrm{CH}_{3} \mathrm{OH}(200: 1$, v/v) as eluent, affording compound 3 (Scheme S1) as dark brown solid (189 mg, yield 65\%). ${ }^{1} \mathrm{H}$ NMR (400 MHz, $\left.298 \mathrm{~K}, \mathrm{CDCl}_{3}\right): \delta 9.02(\mathrm{~d}, 2 \mathrm{H}, \mathrm{J}=3.0 \mathrm{~Hz}), 7.77$ (d, 2H, J = 6.0 Hz), $7.70(\mathrm{~s}, 2 \mathrm{H}), 7.58(\mathrm{~d}, 2 \mathrm{H}, \mathrm{J}=6.0 \mathrm{~Hz}), 7.54(\mathrm{~m}, 4 \mathrm{H}), 6.72(\mathrm{~d}, 4 \mathrm{H}, \mathrm{J}=5.0 \mathrm{~Hz}), 4.02(\mathrm{t}, 8 \mathrm{H}$, $\mathrm{J}=6.5 \mathrm{~Hz}), 2.53-2.46(\mathrm{~m}, 4 \mathrm{H}), 2.42-2.35(\mathrm{~m}, 4 \mathrm{H}), 1.69(\mathrm{t}, 8 \mathrm{H}, \mathrm{J}=7.4 \mathrm{~Hz}), 0.85(\mathrm{t}, 8 \mathrm{H}$, $\mathrm{J}=6.5 \mathrm{~Hz}),-0.05(\mathrm{~s}, 36 \mathrm{H}) .{ }^{13} \mathrm{C} \mathrm{NMR}\left(75 \mathrm{MHz}, 298 \mathrm{~K}, \mathrm{CDCl}_{3}\right): \delta 173.9,157.0,151.4$, $150.2,150.1,147.8,142.0,138.5,134.6,132.2,125.7,124.1,121.3,119.8,119.3,115.2$, 113.1, 109.9, 62.6, 53.6, 35.1, 29.4, 17.4, -1.4. HR-MALDI-MS: $\mathrm{m} / \mathrm{z}$ calcd. for compound $3\left(\mathrm{C}_{72} \mathrm{H}_{88} \mathrm{~N}_{6} \mathrm{O}_{8} \mathrm{~S}_{3} \mathrm{SeSi}_{4},\left[\mathrm{M}^{+}\right]\right), 1452.4068$; found, 1452.4088.

Compound 3 (145 mg, $0.1 \mathrm{mmol}$ ) was stirred in 50\% TFA in $\mathrm{CH}_{2} \mathrm{Cl}_{2}$ at $0{ }^{\circ} \mathrm{C}$ for 4 h. The reaction was monitored with HPLC [eluents were $\mathrm{MeOH} / \mathrm{H}_{2} \mathrm{O}(\mathrm{v} / \mathrm{v})$ : from 8:2 to 10:0 in $30 \mathrm{~min}$; total flow rate, $1 \mathrm{~mL} / \mathrm{min}$ ]. After completion, the solvent was evaporated by a rotary evaporator and the residue was subjected to C18 column chromatography with $\mathrm{MeOH} / \mathrm{H}_{2} \mathrm{O}$ (7:3 to 9:1, v/v) as eluent, affording FM1210 as dark brown solid (63 mg, yield 60\%). ${ }^{1} \mathrm{H}$ NMR (300 MHz, $298 \mathrm{~K}$, DMSO-d 6 ): $\delta 9.09$ (d, 2H, $\mathrm{J}=3.9 \mathrm{~Hz}), 7.96(\mathrm{~s}, 2 \mathrm{H}), 7.87-7.80(\mathrm{~m}, 6 \mathrm{H}), 7.74(\mathrm{~d}, 2 \mathrm{H}, \mathrm{J}=7.8 \mathrm{~Hz}), 7.02(\mathrm{~s}, 1 \mathrm{H}), 6.95$ $(\mathrm{d}, 2 \mathrm{H}, \mathrm{J}=7.8 \mathrm{~Hz}), 2.30(\mathrm{~m}, 4 \mathrm{H}), 2.29-2.28(\mathrm{~m}, 4 \mathrm{H}), 1.47(\mathrm{t}, 3 \mathrm{H}) .{ }^{13} \mathrm{C}$ NMR $(100 \mathrm{MHz}$, 298 K, DMSO-d 6 ): $\delta$ 174.4, 165.0, 156.6, 151.0, 150.7, 149.5, 148.7, 141.8, 138.1, 134.6, 133.1, 134.0, 132.0, 125.6, 125.1, 121.8, 120.0, 120.0, 112.6, 53.7, 34.7, 29.4. HR-MALDI-MS: $m / z$ calcd. for FM1210 $\left(\mathrm{C}_{52} \mathrm{H}_{40} \mathrm{~N}_{6} \mathrm{O}_{8} \mathrm{~S}_{3} \mathrm{Se},[\mathrm{M}]^{+}\right), 1052.1235$; found, 1052.1253.

Synthesis and characterization of compound 8. Compound 4 was synthesized according to the previous literature. ${ }^{1}$ Under the protection of $\mathrm{N}_{2}$, THF $(2.5 \mathrm{~mL})$ and 0.5 

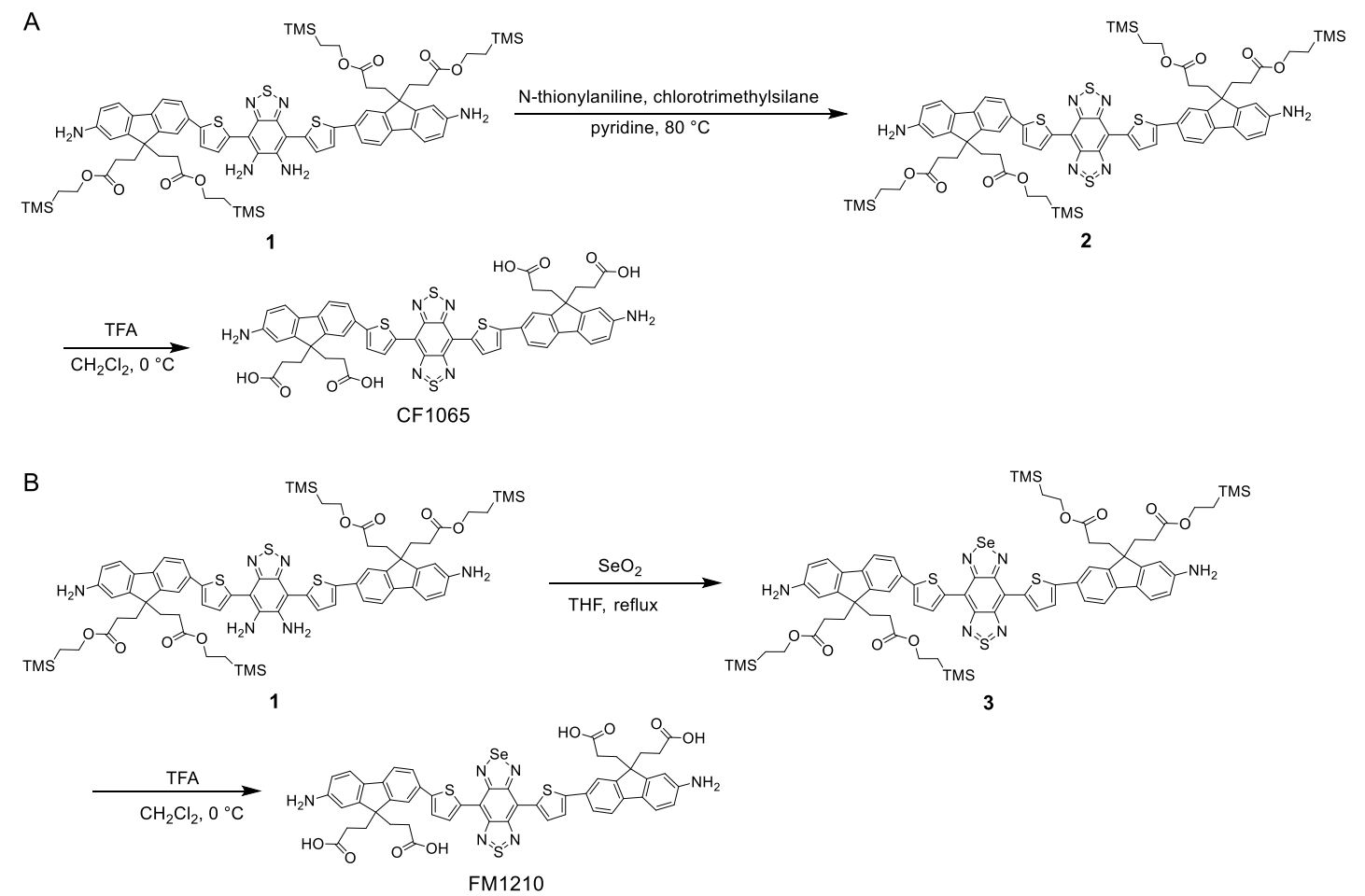

C
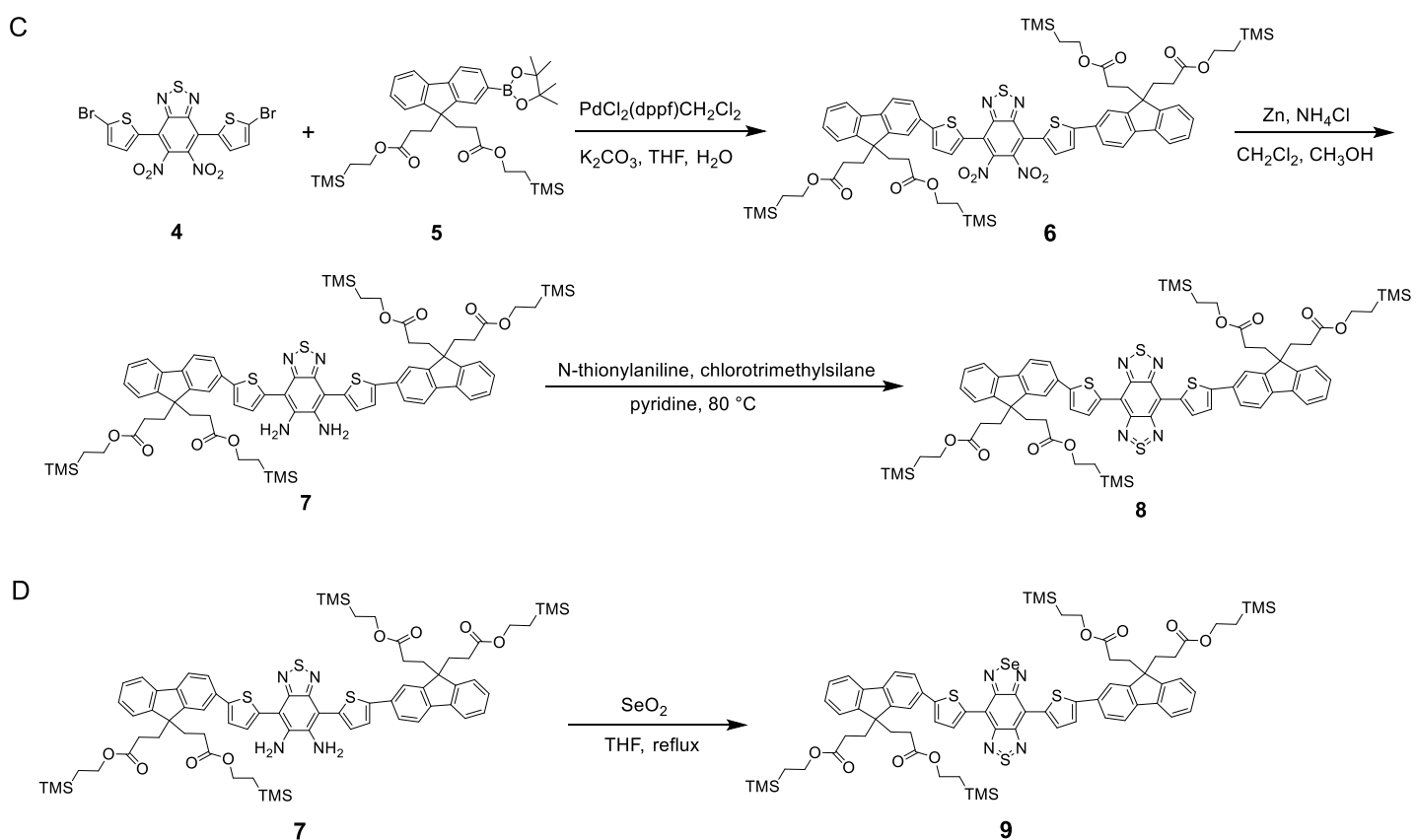

Scheme S1. Syntheses of (A) CF1065, (B) FM1210, (C) compound 8 and (D) compound 9.

$\mathrm{mL}$ water were added to a mixture of 9,9-bis[2-(trimethylsilyl)ethyl]ester (compound $\mathbf{5}$; $64 \mathrm{mg}, 0.1 \mathrm{mmol})$, compound 4 (27 mg, $0.05 \mathrm{mmol}), \mathrm{K}_{2} \mathrm{CO}_{3}(18 \mathrm{mg}, 0.125 \mathrm{mmol})$ and 1,1'-bis(diphenylphosphino)ferrocenepalladium(II)dichloride dichloromethane complex ( $9 \mathrm{mg}, 0.01 \mathrm{mmol})$. The mixture was refluxed at $75^{\circ} \mathrm{C}$ for $14 \mathrm{~h}$. After cooling to room temperature, the solvent was removed in vacuo. The residue was dissolved in 
$\mathrm{CH}_{2} \mathrm{Cl}_{2}$, and the resulting solution was washed with saturated aqueous brine. After drying over anhydrous $\mathrm{Na}_{2} \mathrm{SO}_{4}$ and removal of the solvent under reduced pressure, compound 6 (60 mg, 85\% yield) was obtained as a dark red solid, which was used directly in the next step.

Zinc dust (180 mg, $3 \mathrm{mmol})$ and $\mathrm{NH}_{4} \mathrm{Cl}(48 \mathrm{mg}, 0.9 \mathrm{mmol})$ were added to a stirred solution of compound 6 (130 mg, $0.05 \mathrm{mmol})$ in $\mathrm{CH}_{2} \mathrm{Cl}_{2}(7.2 \mathrm{~mL})$ and $\mathrm{MeOH}(11.4 \mathrm{~mL})$ under the protection of $\mathrm{N}_{2}$. After stirring at room temperature for $4 \mathrm{~h}$, the solution was filtered, diluted with $\mathrm{CH}_{2} \mathrm{Cl}_{2}$, and washed with saturated aqueous $\mathrm{NaHCO}_{3}$ and saturated salt solution. The organic phase was dried over anhydrous $\mathrm{Na}_{2} \mathrm{SO}_{4}$, and evaporated under vacuum to afford compound $\mathbf{7}$ as a dark yellow-green solid, which was used directly without further purification.

To a dark yellow-green solution of compound 7 in anhydrous pyridine $(1 \mathrm{~mL})$ were added $N$-thionylaniline $(0.2 \mathrm{~mL}, 1.8 \mathrm{mmol})$ and chlorotrimethylsilane $(0.3 \mathrm{~mL}$, $3.5 \mathrm{mmol}$ ). The mixture was stirred at $80^{\circ} \mathrm{C}$ for $24 \mathrm{~h}$. After cooling to room temperature, the mixture was extracted with $\mathrm{CH}_{2} \mathrm{Cl}_{2}$. The organic layer was washed with saturated salt solution, dried over anhydrous $\mathrm{Na}_{2} \mathrm{SO}_{4}$, and concentrated in vacuo. The residue was purified by flash column chromatography on silica gel (petroleum ether:ethyl acetate from 20:1 to $10: 1$ ) to yield compound 8 as a yellow solid (34 mg, yield 51\%). ${ }^{1} \mathrm{H} \mathrm{NMR}$ (400 MHz, $\left.298 \mathrm{~K}, \mathrm{CDCl}_{3}\right): \delta 8.75(\mathrm{~d}, 2 \mathrm{H}, \mathrm{J}=4.0 \mathrm{~Hz}), 7.76-7.69(\mathrm{~m}, 8 \mathrm{H}), 7.45-7.37$ (m, $8 \mathrm{H}), 4.00(\mathrm{t}, 8 \mathrm{H}, \mathrm{J}=7.0 \mathrm{~Hz}), 2.58(\mathrm{~m}, 8 \mathrm{H}), 1.82-1.74(\mathrm{~m}, 4 \mathrm{H}), 1.71-1.63(\mathrm{~m}, 4 \mathrm{H}), 0.85$ $(\mathrm{t}, 3 \mathrm{H}, \mathrm{J}=8.6),-0.048(\mathrm{~s}, 36 \mathrm{H}) .{ }^{13} \mathrm{C} \mathrm{NMR}\left(100 \mathrm{MHz}, 298 \mathrm{~K}, \mathrm{CDCl}_{3}\right): \delta 173.7,150.6$, $149.1,148.8,148.1,141.4,140.9,137.6$, 134.0, 133.7, 127.9, 125.8, 124.3, 123.2, 120.7, 120.3, 120.0, 113.0, 62.6, 54.0, 29.4, 17.4, -1.5. HR-MALDI-MS: $\mathrm{m} / \mathrm{z}$ calcd. for compound $8\left(\mathrm{C}_{72} \mathrm{H}_{86} \mathrm{~N}_{4} \mathrm{O}_{8} \mathrm{~S}_{4} \mathrm{Si}_{4},[\mathrm{M}]^{+}\right)$, 1374.4406; found, 1374.4409.

Synthesis and characterization of compound 9. Following a similar procedure as for compound 3 above, compound 9 was synthesized as a brown solid (yield 65\%) by the reaction of compound 7 with $\mathrm{SeO}_{2} .{ }^{1} \mathrm{H} \mathrm{NMR}\left(400 \mathrm{MHz}, 298 \mathrm{~K}, \mathrm{CDCl}_{3}\right): \delta 8.88(\mathrm{~d}, 2 \mathrm{H}$, $\mathrm{J}=4.0 \mathrm{~Hz}), 7.76-7.70(\mathrm{~m}, 8 \mathrm{H}), 7.50-7.37(\mathrm{~m}, 8 \mathrm{H}), 4.00(\mathrm{t}, 8 \mathrm{H}, \mathrm{J}=7.2 \mathrm{~Hz}), 2.58-2.52$ (m, 8H), 1.77-1.71 (m, 4H), 1.69-1.63 (m, 4H), 0.85 (t, 3H, J = 8.6), -0.052 (s, 36 H). ${ }^{13} \mathrm{C} \mathrm{NMR}\left(100 \mathrm{MHz}, 298 \mathrm{~K}, \mathrm{CDCl}_{3}\right): \delta 173.9,157.1,151.5,149.9,149.0,148.3,141.5$, 141.1, 139.0, 134.8, 134.0, 128.1, 125.9, 124.6, 123.4, 120.9, 120.5, 120.2, 113.3, 62.8, 54.1, 35.1, 29.6, 17.5, -1.3. HR-MALDI-MS: $\mathrm{m} / \mathrm{z}$ calcd. for compound 9 $\left(\mathrm{C}_{72} \mathrm{H}_{86} \mathrm{~N}_{4} \mathrm{O}_{8} \mathrm{~S}_{3} \mathrm{SeSi}_{4},[\mathrm{M}]^{+}\right), 1422.3850$; found, 1422.3819 . 
Photophysical data. The fluorescence quantum yield $(\Phi)$ was measured in a similar manner as described in the previous report. ${ }^{2}$ Briefly, $\Phi$ was measured using IR-26 $(\Phi=$ $0.05 \%$ in dichloroethane) as a standard, ${ }^{3}$ and was calculated using the following equation: $\Phi_{X}=\Phi_{S}\left(R_{X} / R_{S}\right)\left(\eta_{X}^{2} / \eta_{S}^{2}\right)$, where the subscripts $S$ and $X$ denote the standard and test sample, respectively; $\mathrm{R}$ is the slope from the plot of integrated fluorescence intensity vs. absorbance; and $\eta$ is the refractive index of the solvents. For IR-26 and CF1065, the excitation wavelength was at $808 \mathrm{~nm}$ while keeping the absorbance below 0.05; for FM1210, the excitation wavelength was at $980 \mathrm{~nm}$ while keeping the absorbance below 0.05 .

Cell culture and cytotoxicity assay. HeLa cells were grown on glass-bottom culture dishes (MatTek Co.) in DMEM supplemented with 10\% (v/v) FBS and 1\% (v/v) penicillin-streptomycin at $37{ }^{\circ} \mathrm{C}$ in a humidified $5 \% \mathrm{CO}_{2}$ incubator. The cytotoxicity of FM1210 and FM1210-NPs to HeLa cells was evaluated using MTT assay as described previously. $^{4}$

In vivo imaging of mice. Five-week-old female $\mathrm{BALB} / \mathrm{c}$ nude mice were obtained from Beijing Vital River Laboratory Animal Technology Co., Ltd. All animal care and experimental protocols complied with the Animal Management Rules of the Ministry of Health of the People's Republic of China and were approved by the Institute of Process Engineering, Chinese Academy of Sciences. HeLa tumor-bearing mice were obtained by injection of $1 \times 10^{6} \mathrm{HeLa}$ cells suspended in $150 \mu \mathrm{L}$ PBS on the lateral thigh of each mouse. After two weeks, tumor-bearing mice were used in our experiments.

Synthesis and characterization of FM1210-NPs. A 1-mL FM1210 solution (1 $\mathrm{mg} / \mathrm{mL}$ in THF) was added into $9 \mathrm{~mL}$ water containing $9 \mathrm{mg}$ DSPE-mPEG ${ }_{5000}$. After stirring at room temperature for $12 \mathrm{~h}$, the mixture was centrifuged at $9000 \mathrm{rpm}$ for 15 min using $30 \mathrm{kDa}$ cut-off filter (Millipore). The crude product was purified first by washing with water and ultrasonic treatment for 5 times. Then, the crude product was dissolved in $4 \mathrm{~mL}$ water, followed by ultracentrifugation at 50,000 rpm for $30 \mathrm{~min}$. Lyophilization of the supernatant gave the desired product FM1210-NPs. Finally, FM1210-NPs was dissolved in PBS or saline at a concentration of $20 \mathrm{mg} / \mathrm{mL}$ as the stock solution for subsequent experiments. The content of FM1210 in FM1210-NPs can be estimated by using the corrected absorbance (i.e., minus the blank absorbance) of FM1210-NPs and the corresponding molar absorptivity $\left(1.09 \times 10^{4} \mathrm{M}^{-1} \mathrm{~cm}^{-1}\right)$ of FM1210 at $930 \mathrm{~nm}$ in PBS. 


\section{Additional Tables and Figures}

Table S1. Comparison of NIR-II fluorophores

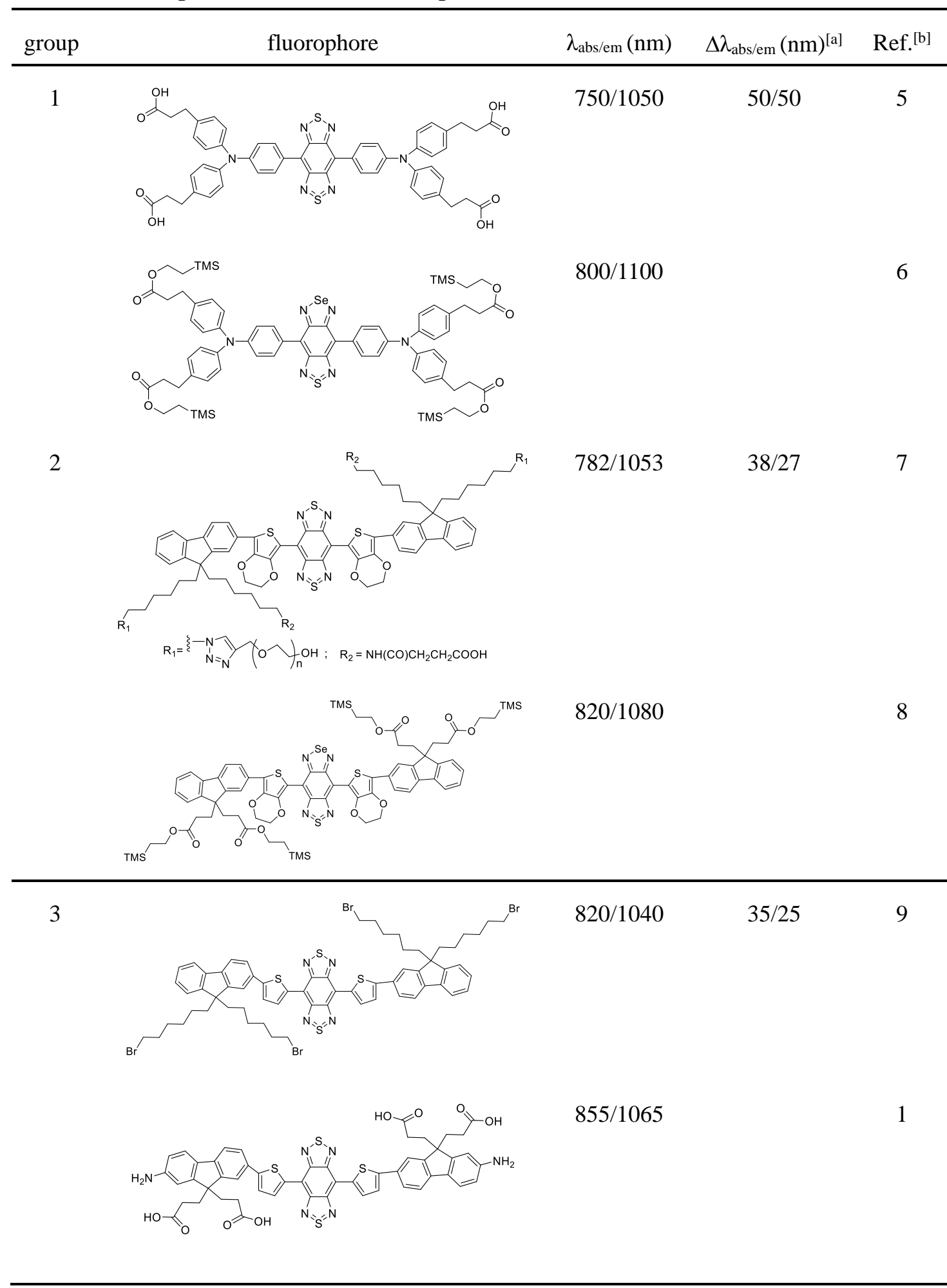

${ }^{[a]} \Delta \lambda_{\text {abs/em }}$ is the difference of the corresponding maximal absorption and emission wavelengths between the fluorophore in the second-line and the fluorophore in the first-line. ${ }^{[b]}$ In ref. 1 and ref. 9, the fluorophore was in $\mathrm{CH}_{2} \mathrm{Cl}_{2}$ and toluene, respectively; other data including the concentrations are unavailable. 

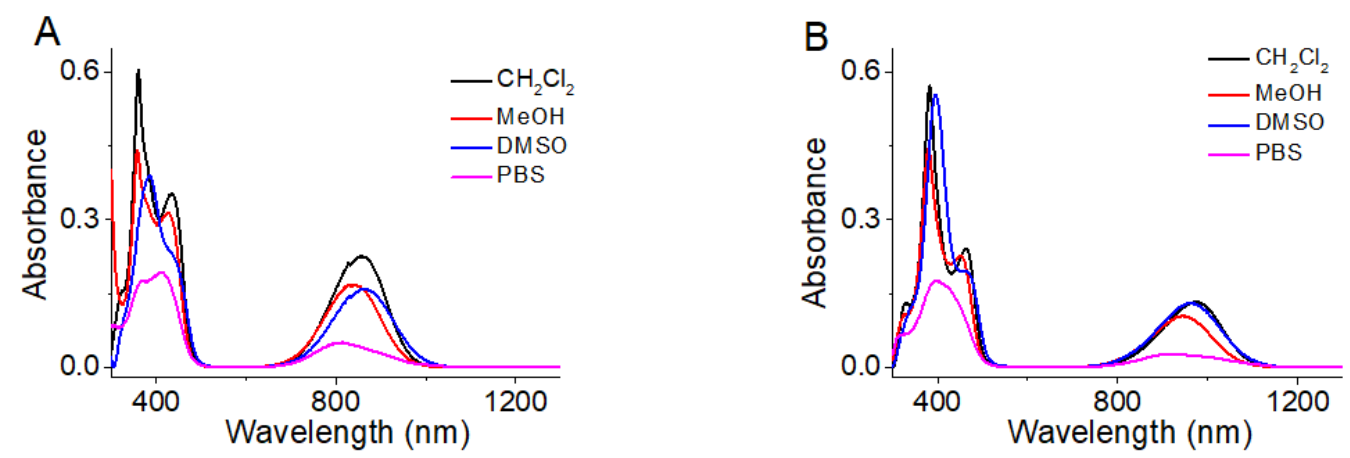

Figure S1. Absorption spectra of (A) CF1065 and (B) FM1210 in different solvents.

Table S2. Photophysical data of CF1065 and FM1210

\begin{tabular}{lllllll}
\hline compound & solvent & $\begin{array}{l}\lambda_{\text {abs }} \\
(\mathrm{nm})^{[\mathrm{a}]}\end{array}$ & $\begin{array}{l}\varepsilon \\
\left(10^{4} \mathrm{M}^{-1} \mathrm{~cm}^{-1}\right)^{[\mathrm{b}]}\end{array}$ & $\begin{array}{l}\lambda_{\mathrm{em}} \\
(\mathrm{nm})^{[\mathrm{c}]}\end{array}$ & $\begin{array}{l}\Phi \\
(\%)\end{array}$ & $\begin{array}{l}\text { brightness } \\
\left(\mathrm{M}^{-1} \mathrm{~cm}^{-1}\right)\end{array}$ \\
\hline CF1065 & DCM & 855 & $3.01 \pm 0.5$ & 1065 & $0.041 \pm 0.005$ & $12 \pm 3$ \\
& MeOH & 825 & $2.36 \pm 0.4$ & 1045 & $0.013 \pm 0.002$ & $3 \pm 1$ \\
& DMSO & 860 & $3.31 \pm 0.7$ & 1090 & $0.012 \pm 0.002$ & $3 \pm 1$ \\
& PBS & 820 & $1.31 \pm 0.4$ & 1090 (nearly flat) & $<0.01$ & - \\
\hline \multirow{2}{*}{ FM1210 } & DCM & 980 & $2.72 \pm 0.4$ & 1210 & $0.036 \pm 0.003$ & $10 \pm 2$ \\
& MeOH & 945 & $1.84 \pm 0.2$ & 1200 & $0.012 \pm 0.001$ & $2 \pm 0.1$ \\
& DMSO & 960 & $2.47 \pm 0.3$ & 1250 & $0.017 \pm 0.004$ & $4 \pm 1$ \\
& PBS & 930 & $1.09 \pm 0.2$ & 1250 (nearly flat) & $<0.01$ & - \\
\hline
\end{tabular}

${ }^{\text {[a] }}$ Absorption peak. ${ }^{[b]}$ Molar absorptivity of the corresponding absorption peak.

${ }^{[c]}$ Fluorescence emission peak.

A

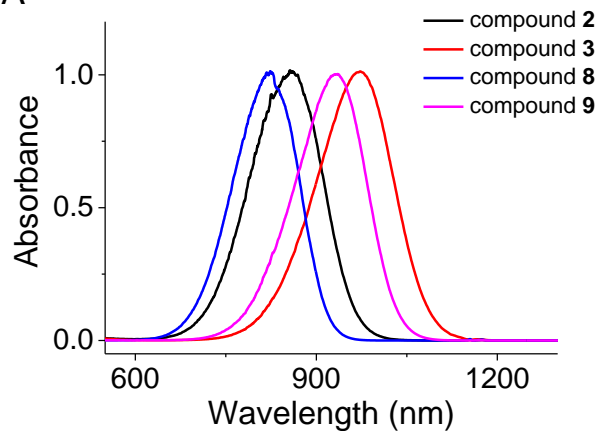

B

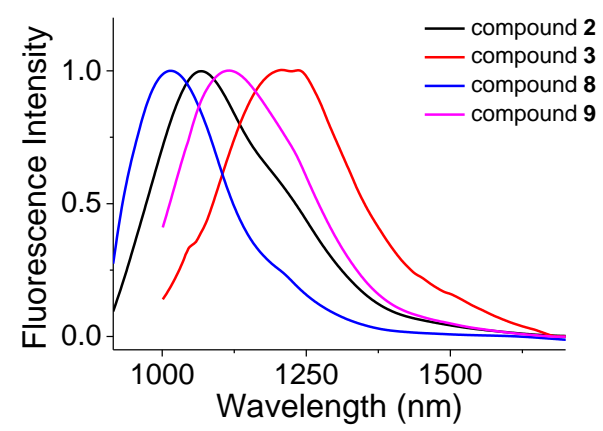

Figure S2. (A) Normalized absorption and (B) fluorescence spectra of compounds 2, $\mathbf{3}, \mathbf{8}$, and 9 in $\mathrm{CH}_{2} \mathrm{Cl}_{2}$. The fluorescence spectra of compounds 2 and $\mathbf{8}$ were measured under the excitation of $808 \mathrm{~nm}$, and those of compounds $\mathbf{3}$ and $\mathbf{9}$ under the excitation of $980 \mathrm{~nm}$. 
Table S3. The HOMO-LUMO gaps of different compounds

compound structure and wavelength ${ }^{[\mathrm{a}]}$

3
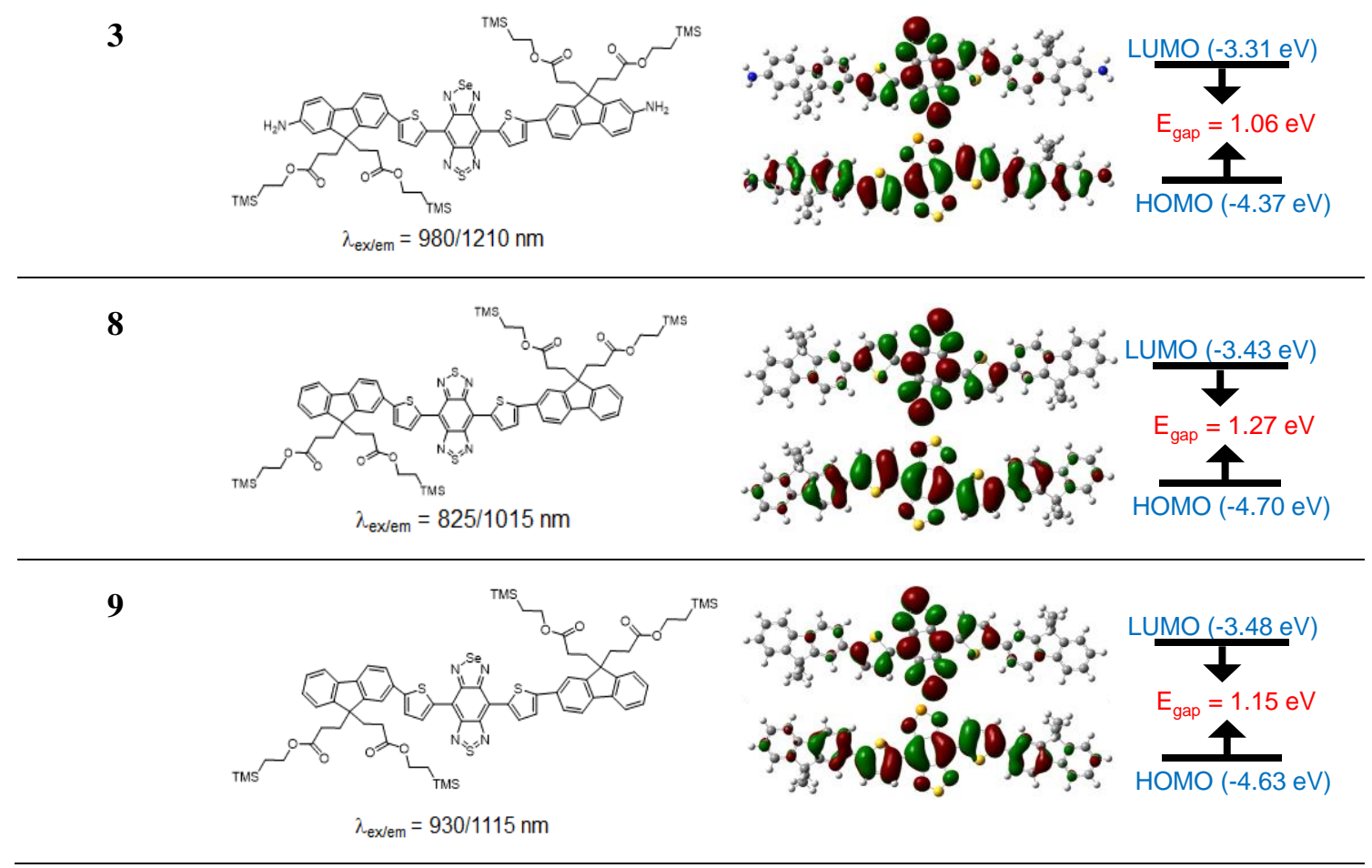

${ }^{[\mathrm{a}]}$ The wavelengths of compounds were measured in $\mathrm{CH}_{2} \mathrm{Cl}_{2}$.

${ }^{[b]}$ Calculations were made at the B3LYP/6-31G(d) level with Gaussian 09 software. To reduce the computational requirements, the side chains on the fluorene units are replaced by methyl groups. Note: the energy gap between the highest occupied molecular orbital (HOMO) and the lowest unoccupied molecular orbital (LUMO) is called the HOMO-LUMO gap ( $\left.\mathrm{E}_{\text {gap }}=\mathrm{E}_{\mathrm{LUMO}}-\mathrm{E}_{\text {Hомо }}\right)$.
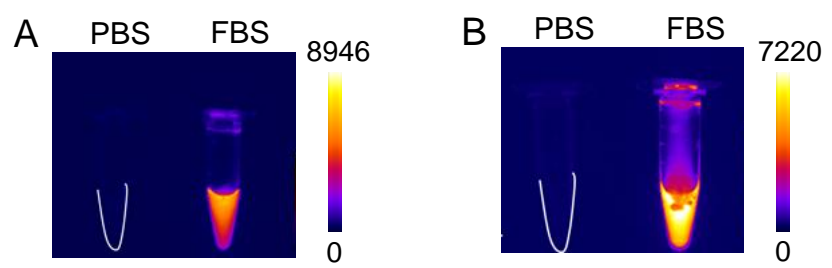

Figure S3. The NIR-II fluorescence images of $10 \mu \mathrm{M}$ of CF1065 and FM1210. (A) CF1065 and (B) FM1210 in PBS and fetal bovine serum (FBS), respectively. (A) ET $=10 \mathrm{~ms}$; (B) ET = $50 \mathrm{~ms}$. The tube shape in PBS is marked with white dot line. The nearby pseudo-color strips show the relative pixel intensity values in the images. 

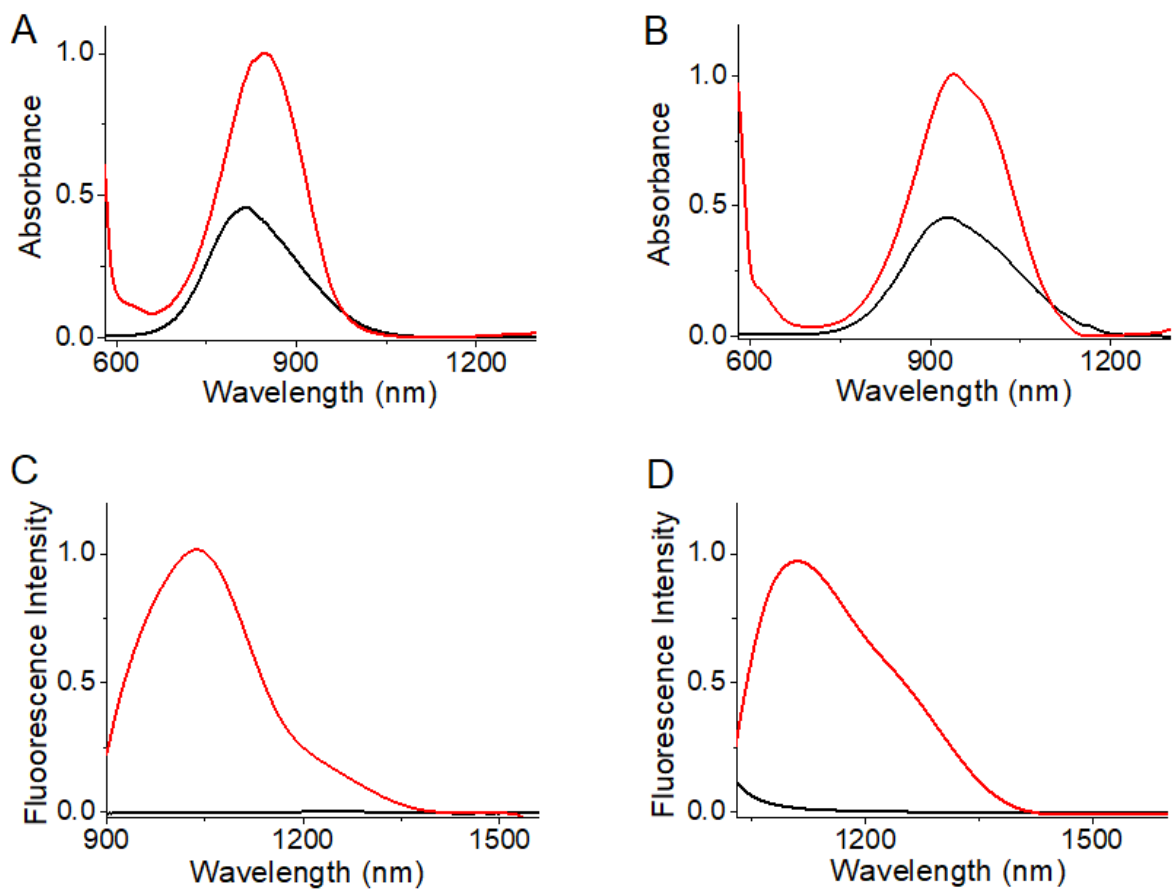

Figure S4. Absorption and fluorescence spectra of $10 \mu \mathrm{M}$ of CF1065 (A and C) and FM1210 (B and D) in pH 7.4 PBS (black curve) and FBS (red curve).
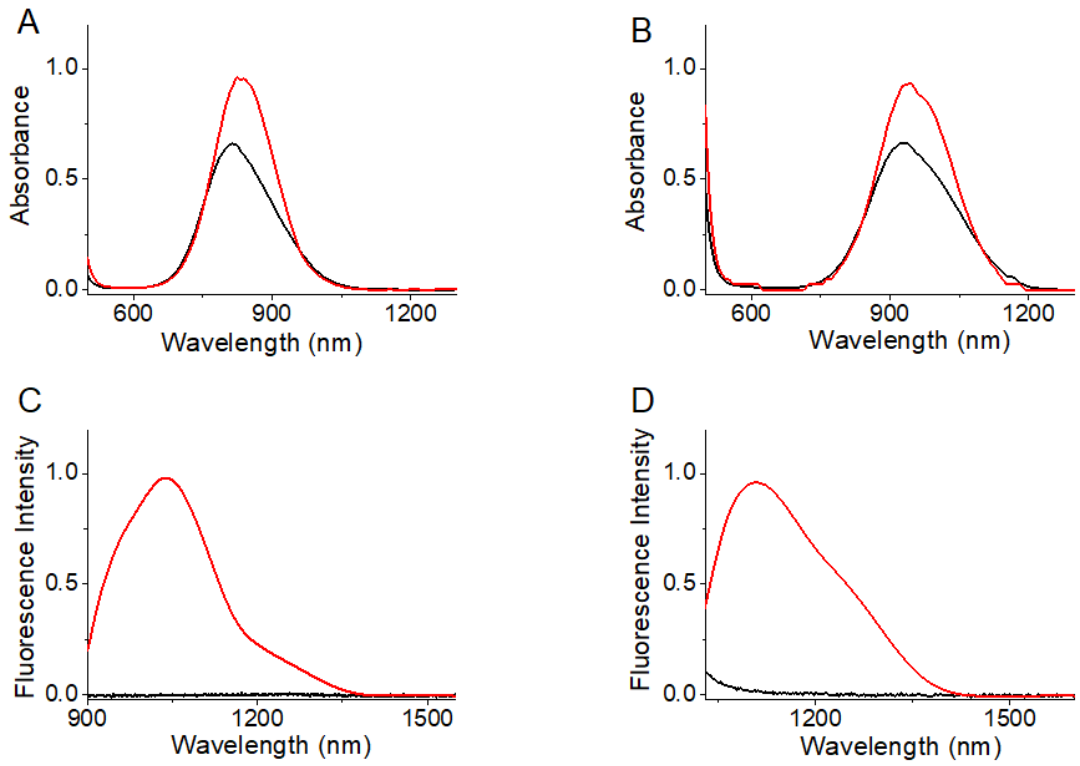

Figure S5. Absorption and fluorescence spectra of $10 \mu \mathrm{M}$ of CF1065 (A and C) and FM1210 (B and D) in pH 7.4 PBS with (red curve) and without (black curve) albumin $(100 \mu \mathrm{M})$. 

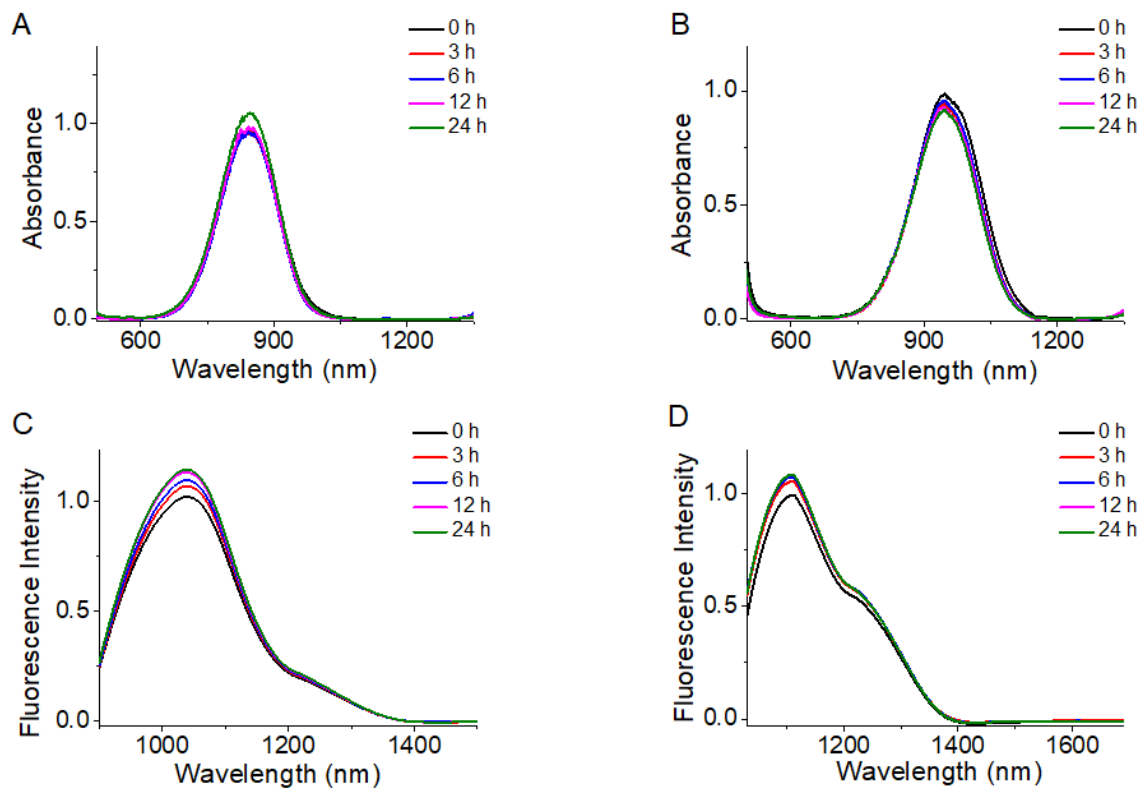

Figure S6. The stability of CF1065 and FM1210. Absorption and fluorescence spectra of $10 \mu \mathrm{M}$ of CF1065 (A and C) and FM1210 (B and D) in FBS at room temperature over $24 \mathrm{~h}$.

A

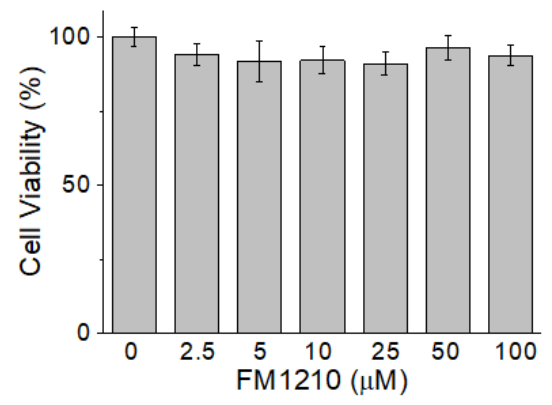

B

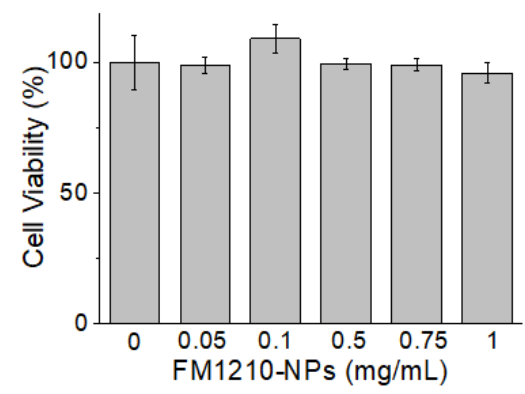

Figure S7. The cell cytotoxicity of fluorophores. Viability changes of HeLa cells after $24 \mathrm{~h}$ of incubation with (A) FM1210 (0-100 $\mu \mathrm{M})$ and (B) FM1210-NPs (0-1 mg/mL). The cell survival without treatment is defined as $100 \%$. The results are the mean \pm standard deviation of 5 independent measurements.

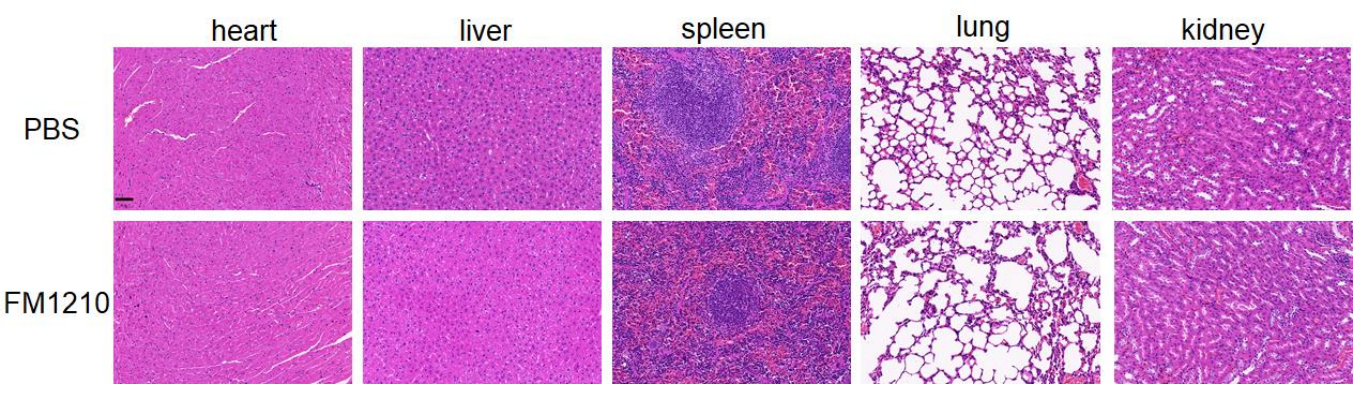

Figure S8. Hematoxylin and eosin-stained images of organs obtained from mice after 14-days intravenous injection of PBS $(150 \mu \mathrm{L})$ or FM1210 $(500 \mu \mathrm{M}, 150 \mu \mathrm{L}, 2 \%$ DMSO). Scale bar: $50 \mu \mathrm{m}$. 
A

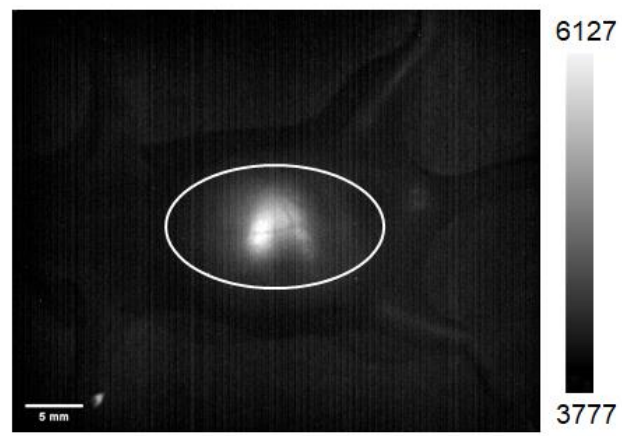

B

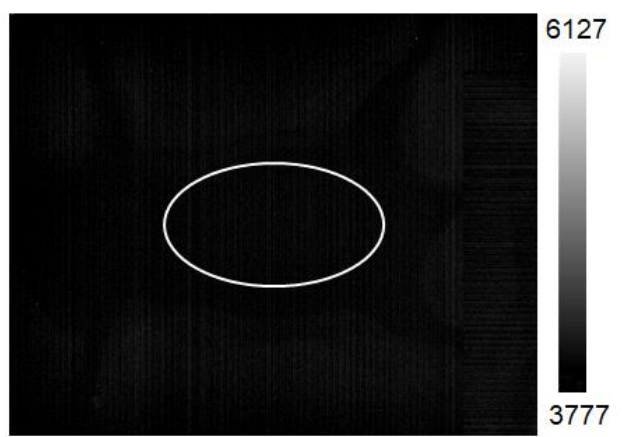

Figure S9. Autofluorescence comparison of the same and representative BALB/c nude mouse $(\mathrm{n}=2)$ under different excitations. (A) $\lambda_{\mathrm{ex}}=808 \mathrm{~nm}$; emission filter: 1000-nm longpass; $\mathrm{ET}=950 \mathrm{~ms}$. (B) $\lambda_{\mathrm{ex}}=980 \mathrm{~nm}$; emission filter: 1150-nm longpass; $\mathrm{ET}=950 \mathrm{~ms}$. Scale bar, $5 \mathrm{~mm}$. The mean relative pixel intensity in the same elliptic region in panels A and B is 4355 and 3784, respectively.
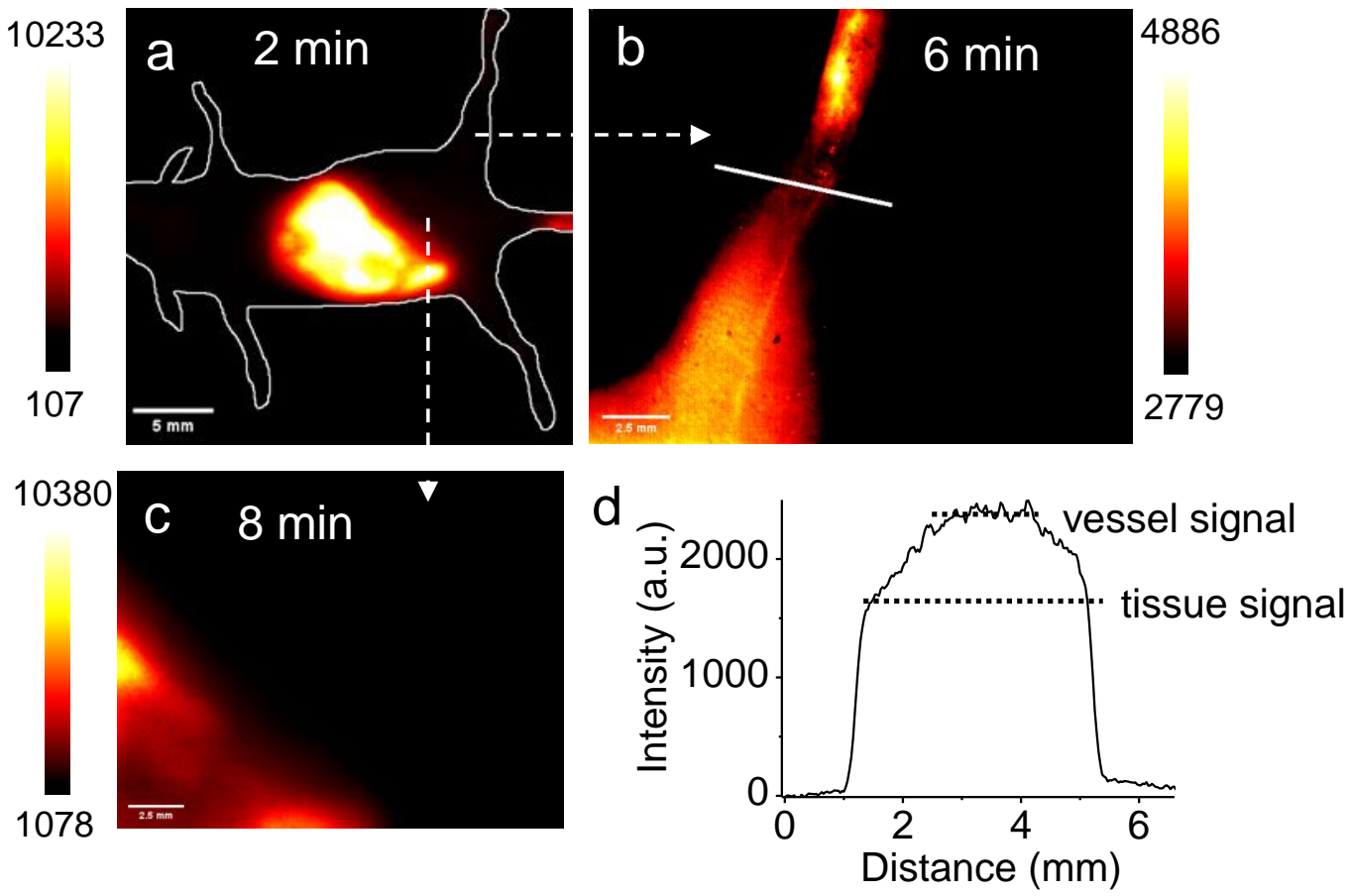

Figure S10. Representative NIR-II fluorescence images of BALB/c nude mice $(n=3)$ with ICG. (a) The fluorescence image of the mouse after intravenous injection with ICG $\left(500 \mu \mathrm{M}\right.$ in $150 \mu \mathrm{L}$ saline solution, $2 \%$ DMSO): $\lambda_{\mathrm{ex}}=808 \mathrm{~nm}, 1000-\mathrm{nm}$ longpass filter, ET $=1 \mathrm{~ms}$. Scale bar, $5 \mathrm{~mm}$. (b) The magnified femoral vascular image $(E T=10 \mathrm{~ms})$. (c) The magnified abdominal vascular image (ET $=2 \mathrm{~ms})$. (d) Intensity profile of the cross-sectional line in image $b$ (note: ICG rapidly concentrated in the liver at the same imaging time points of FM1210 in Figure 2). Scale bar, 2.5 $\mathrm{mm}$ (images $\mathrm{b}$ and $\mathrm{c}$ ). 

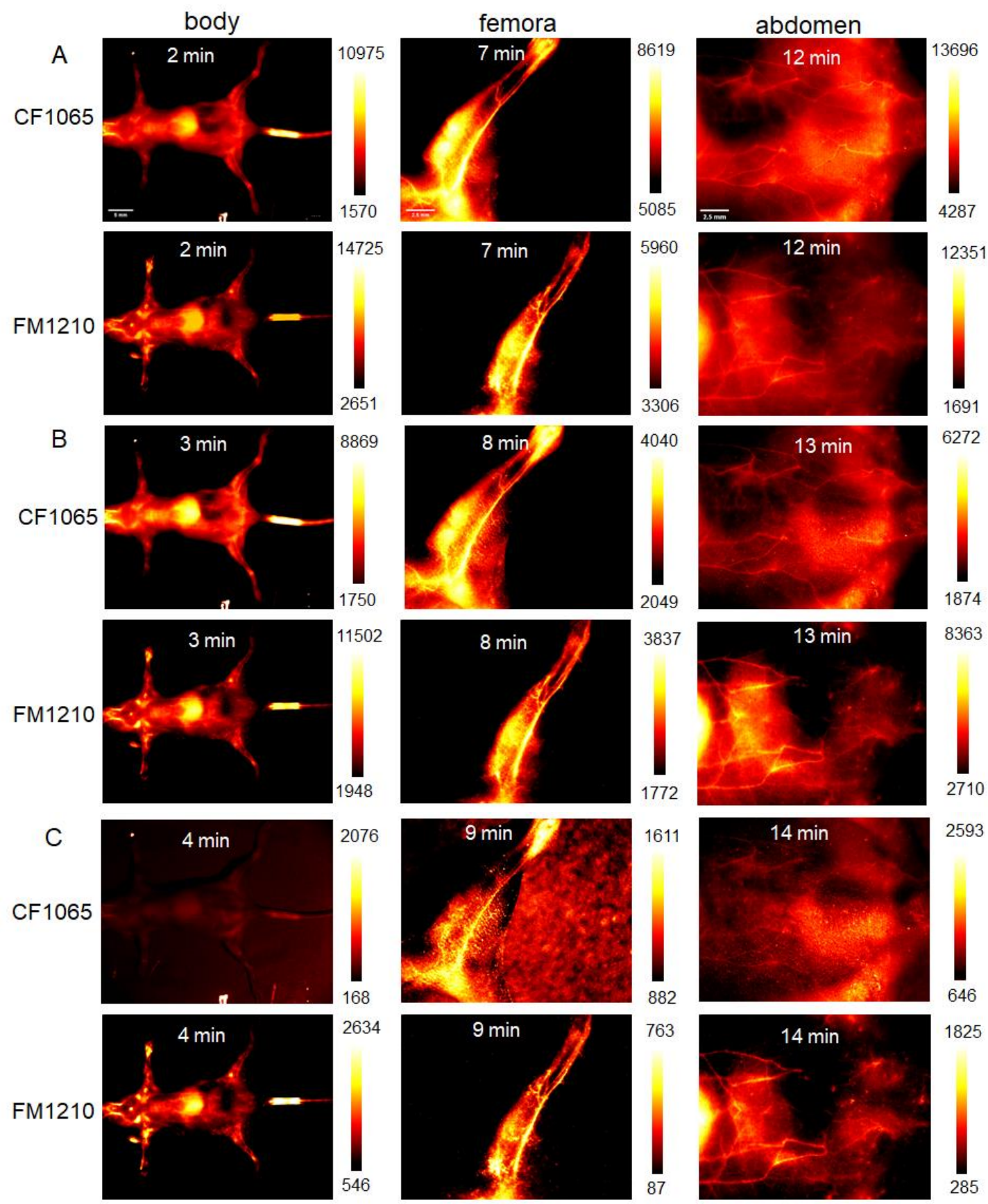

Figure S11. Representative NIR-II fluorescence images of BALB/c nude mice $(n=2)$ with FM1210 $(500 \mu \mathrm{M}, 150 \mu \mathrm{L})$ and CF1065 $(500 \mu \mathrm{M}, 150 \mu \mathrm{L})$. The images were collected with different longpass filters. (A) 1000-nm longpass filter; (B) 1150-nm longpass filter; (C) 1300-nm longpass filter. ET = $15 \mathrm{~ms}$ for body; scale bar, $5 \mathrm{~mm}$. ET $=900 \mathrm{~ms}$ for both femora and abdomen; scale bar, $2.5 \mathrm{~mm}$. 
A
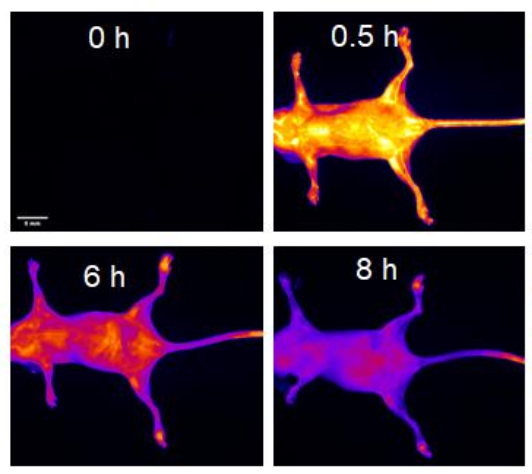

B

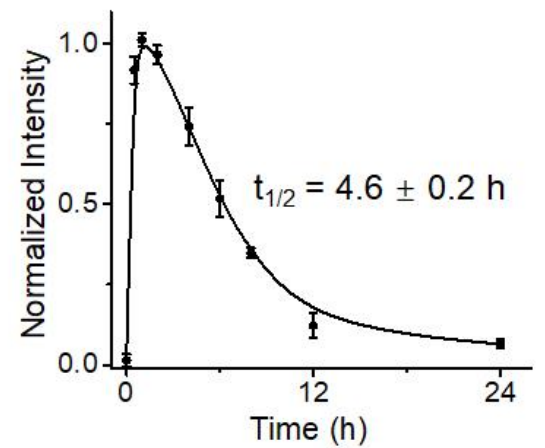

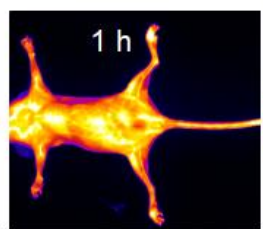

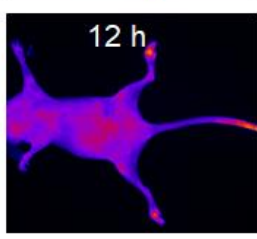

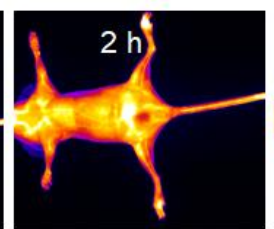

$24 \mathrm{~h}$

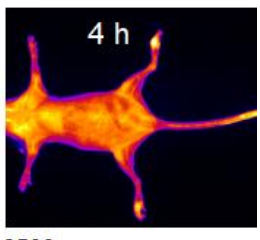

8500

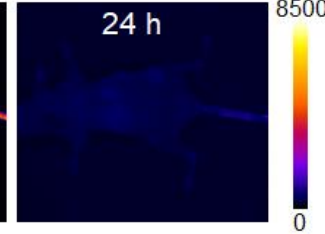

Figure S12. Study on the fluorescence kinetics of FM1210 in blood circulation in mice $(n=3)$. (A) Representative time course images of the mouse after FM1210 (500 $\mu \mathrm{M}, 150 \mu \mathrm{L}$ ) was intravenously injected. ET $=40 \mathrm{~ms}$. Scale bar, $5 \mathrm{~mm}$. (B) The normalized fluorescence intensity of FM1210 in the mice versus time (the maximum mean value of fluorescence intensity in the whole mouse was defined as 1.0; i.e., the 1 h image).
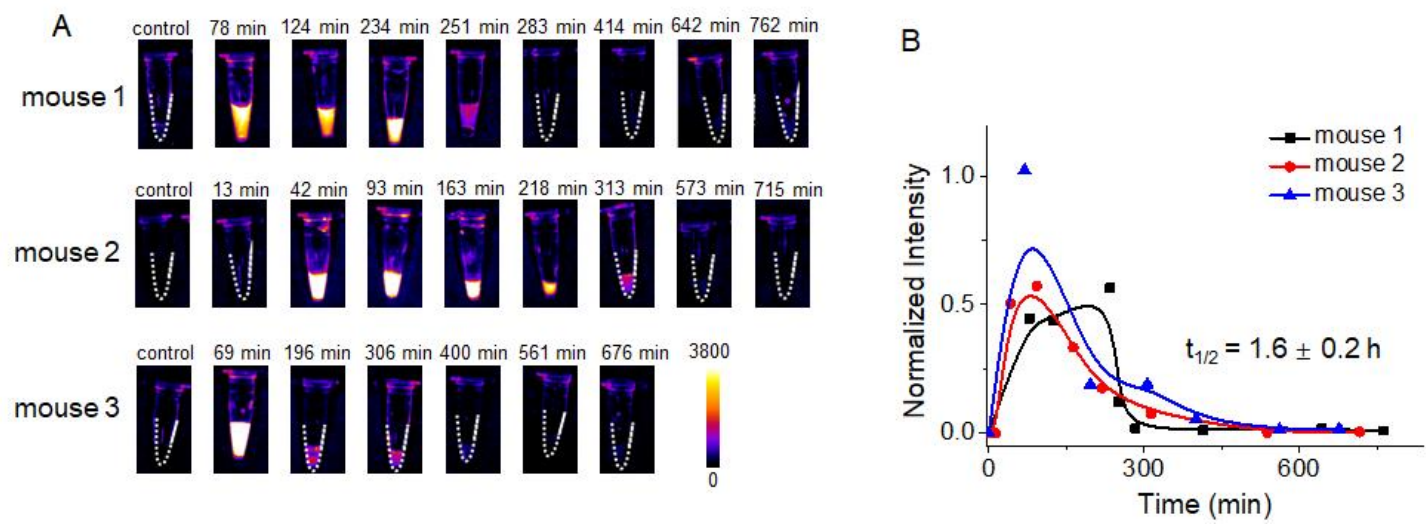

Figure S13. Study on the fluorescence kinetics of FM1210 in the urinary excretion of mice $(n=3)$. (A) The NIR-II fluorescence images of the tubes containing the urine samples of the mice after FM1210 $(500 \mu \mathrm{M}, 100 \mu \mathrm{L})$ was intravenously injected. The urine samples were collected without coercion (control is the urine from the corresponding mouse before injection of FM1210). ET $=495 \mathrm{~ms}$. (B) The normalized fluorescence intensity of the urine samples versus time (the maximum mean value of fluorescence intensity in the same region of the urine sample in the tube was defined as 1.0 ; i.e., the 69 -min image from mouse 3 ). 
A

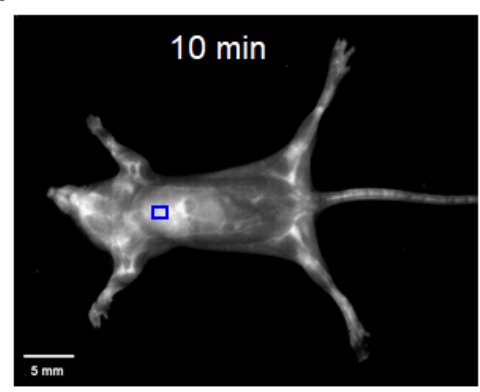

B 3042

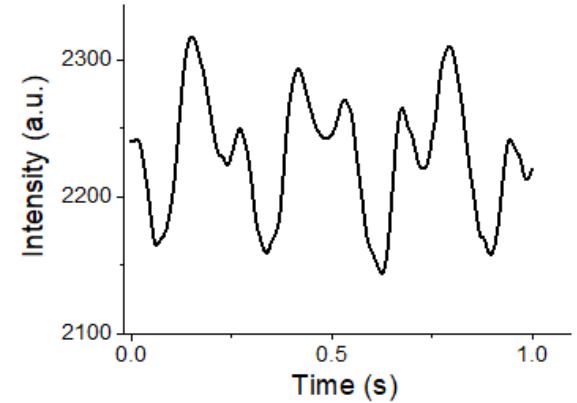

Figure S14. High speed imaging of unanaesthetized mice $(\mathrm{n}=3)$ with the intravenously injected FM1210 (500 $\mu \mathrm{M}$ in $150 \mu \mathrm{L}$ saline solution, 2\% DMSO). (A) Representative image (pseudo color of gray) of the mouse after 10-min injection of FM1210. Blue square indicates the heart region. Images were recorded at $100 \mathrm{fps}$ for $20 \mathrm{~s}$; ET $=10 \mathrm{~ms}$. Scale bar, $5 \mathrm{~mm}$. (B) The heart beat curves recorded by the intensity fluctuation in the heart region.

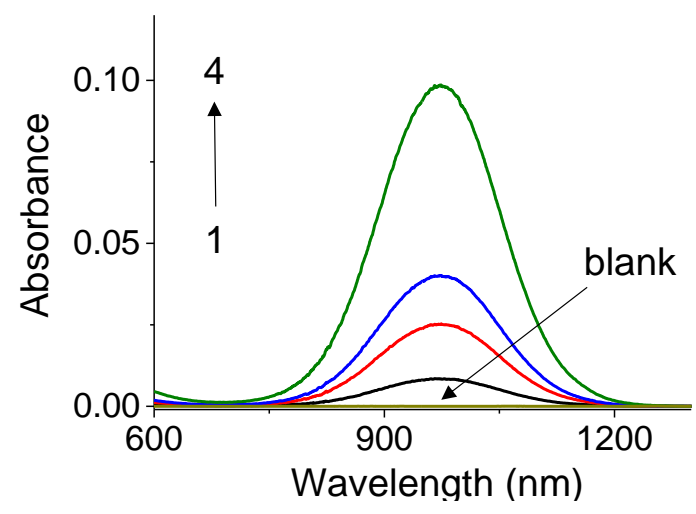

Figure S15. The absorption spectra of FM1210-NPs at different concentrations [0 (blank); curves 1-4: 0.05, 0.10, 0.13 and $0.20 \mathrm{mg} / \mathrm{mL}]$ in PBS.

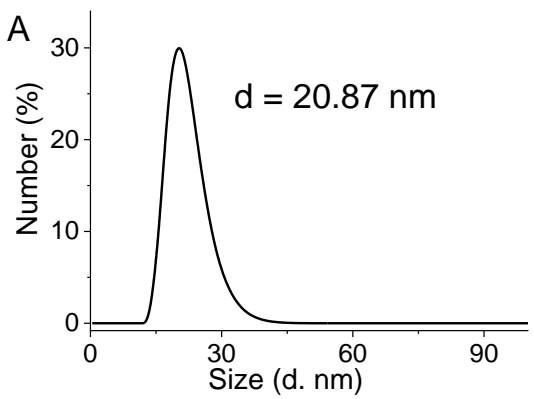

B

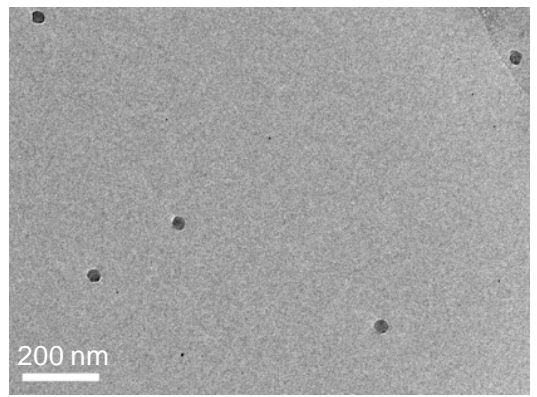

Figure S16. The size distribution of FM1210-NPs. (A) Dynamic light scattering; (B) transmission electron microscopy analyses. 


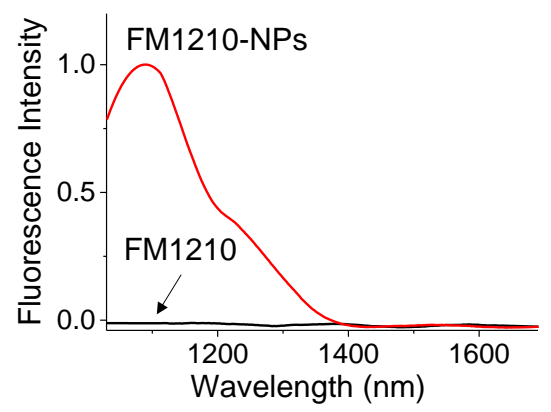

Figure S17. Comparison of fluorescence intensity of FM1210 and FM1210-NPs at the same concentration of $20 \mu \mathrm{M}$ FM1210 (via absorbance measurements) in PBS.

A

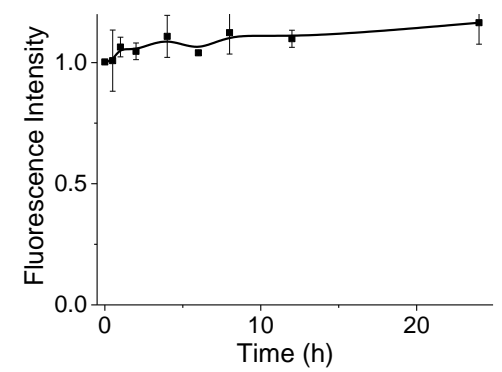

C

(a)

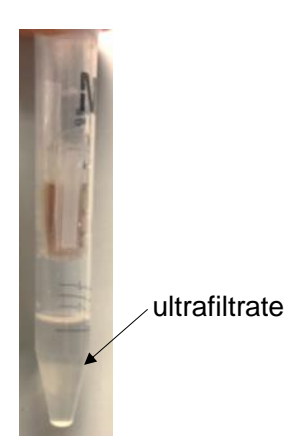

$B$

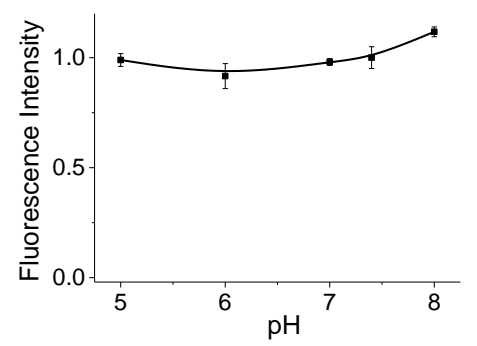

(b)

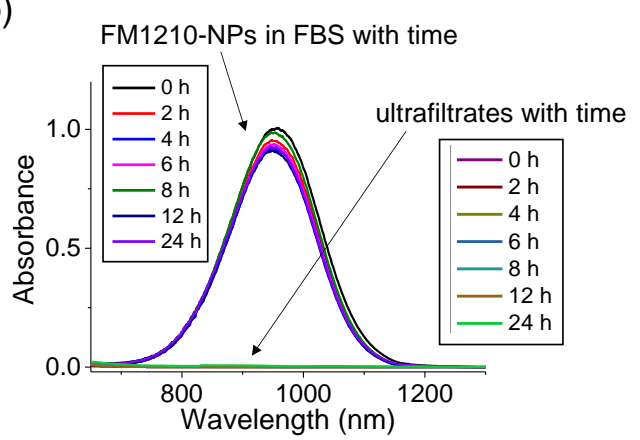

Figure S18. The stability of FM1210-NPs $(0.2 \mathrm{mg} / \mathrm{mL})$. (A) Change of the normalized fluorescence intensity of FM1210-NPs in vitro in FBS over $24 \mathrm{~h}$. (B) Effect of $\mathrm{pH}$ on the normalized fluorescence intensity of FM1210-NPs in PBS with different $\mathrm{pH}$ values. (C) In vivo simulation study on the leak of FM1210 from FM1210-NPs within $24 \mathrm{~h}$. (a) Ultrafiltration tube (30 kDa cut-off filter, which permits the passage of FM1210). Seven ultrafiltration tubes (containing FM1210-NPs in FBS) were subjected to ultrafiltration at seven different time points, and the ultrafiltration was made at $9000 \mathrm{r} / \mathrm{min}$ for $15 \mathrm{~min}$ for each tube. The leak of FM1210 was evaluated by monitoring the change of absorbance at $930 \mathrm{~nm}$ of FM1210 in the ultrafiltrate with time. (b) Absorption spectra of the ultrafiltrates and FM1210-NPs in FBS at different time. As is seen, the absorbance of the ultrafiltrates at $930 \mathrm{~nm}$ is about zero, suggesting no obvious leak of FM1210 from FM1210-NPs. 


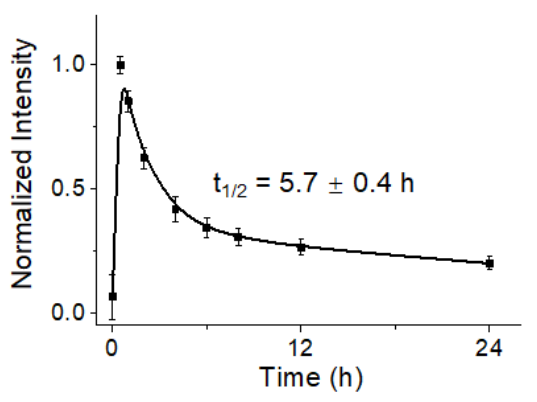

Figure S19. Study on the fluorescence kinetics of FM1210-NPs in blood circulation in mice $(n=5)$. The normalized fluorescence intensity of FM1210-NPs in the mice versus time (the maximum mean value of fluorescence intensity in the whole mouse is defined as 1.0; i.e., the 0.5-h image in Figure $4 \mathrm{C}$ in the main text).

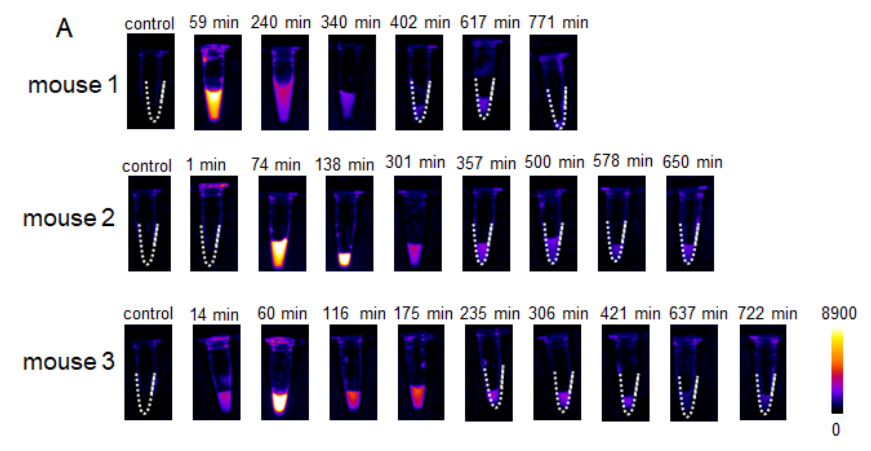

B

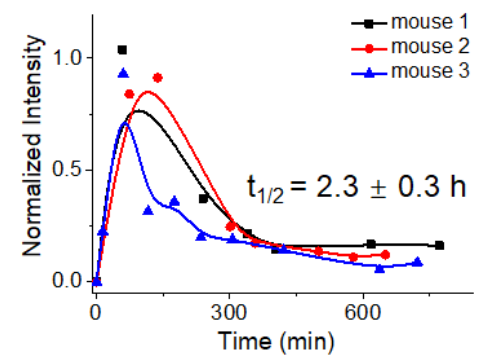

Figure S20. Study on the fluorescence kinetics of FM1210-NPs in the urinary excretion of mice $(n=3)$. (A) The NIR-II fluorescence images of the tubes containing the urine samples of the mice after FM1210-NPs $(100 \mu \mathrm{L}, 20 \mathrm{mg} / \mathrm{mL})$ was intravenously injected. The urine samples were collected without coercion (control is the urine from the corresponding mouse before injection of FM1210-NPs). ET = 495 ms. (B) The normalized fluorescence intensity of the urine samples versus time (the maximum mean value of fluorescence intensity in the same region of the urine sample in the tube was defined as 1.0; i.e., the 59-min image from mouse 1).
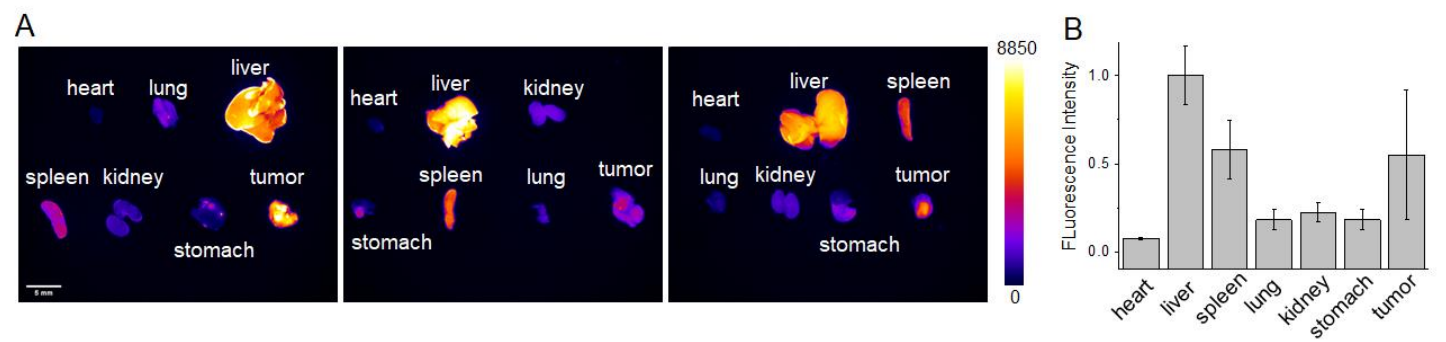

Figure S21. Ex vivo biodistribution of FM1210-NPs in mice. (A) The NIR-II fluorescence images of different organs from three tumor-bearing mice after $24 \mathrm{~h}$ post-injection of FM1210-NPs $(100 \mu \mathrm{L}, 20 \mathrm{mg} / \mathrm{mL})$. ET $=100 \mathrm{~ms}$. Scale bar: $5 \mathrm{~mm}$. (B) Histogram analysis of the relative fluorescence intensity in mice $(n=3)$. 

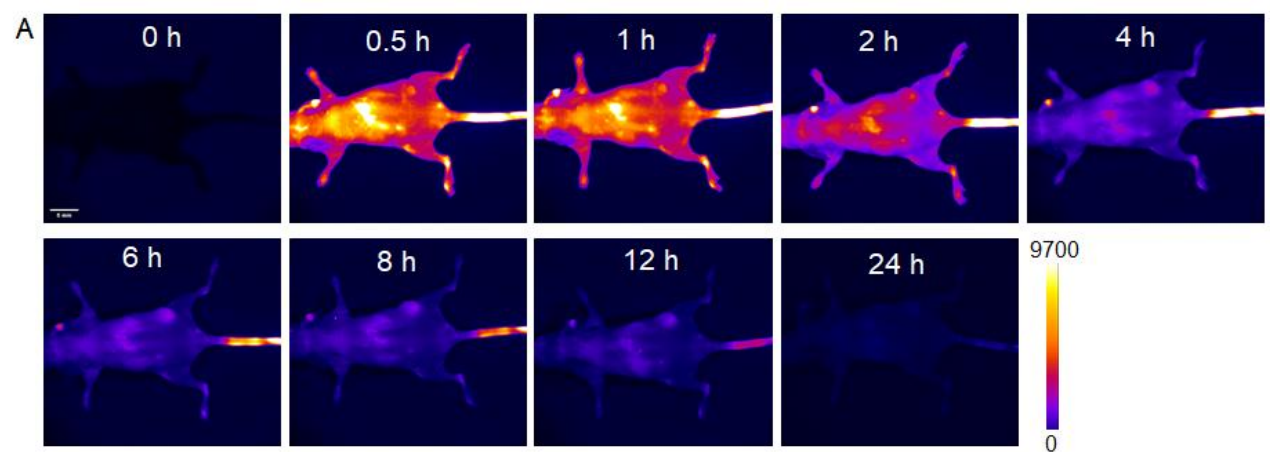

$12 \mathrm{~h}$

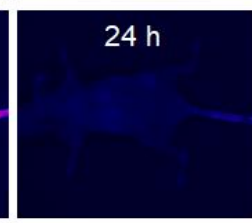

9700
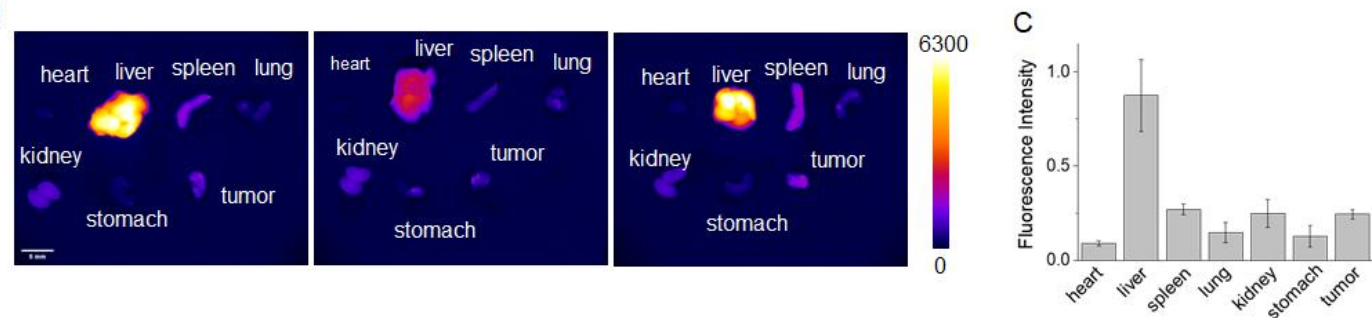

Figure S22. Fluorescence imaging of tumor with FM1210. (A) Representative time course images of the HeLa tumor-bearing mouse $(n=5)$ after FM1210 $(150 \mu \mathrm{L}, 500$ $\mu \mathrm{M})$ was intravenously injected. ET $=195 \mathrm{~ms}$. Scale bar, $5 \mathrm{~mm}$. (B) The NIR-II fluorescence images of different organs from three tumor-bearing mice after $24 \mathrm{~h}$ post-injection of FM1210 $(150 \mu \mathrm{L}, 500 \mu \mathrm{M})$. ET = $195 \mathrm{~ms}$. Scale bar: $5 \mathrm{~mm}$. (C) Histogram analysis of the relative fluorescence intensity in mice $(n=3)$.
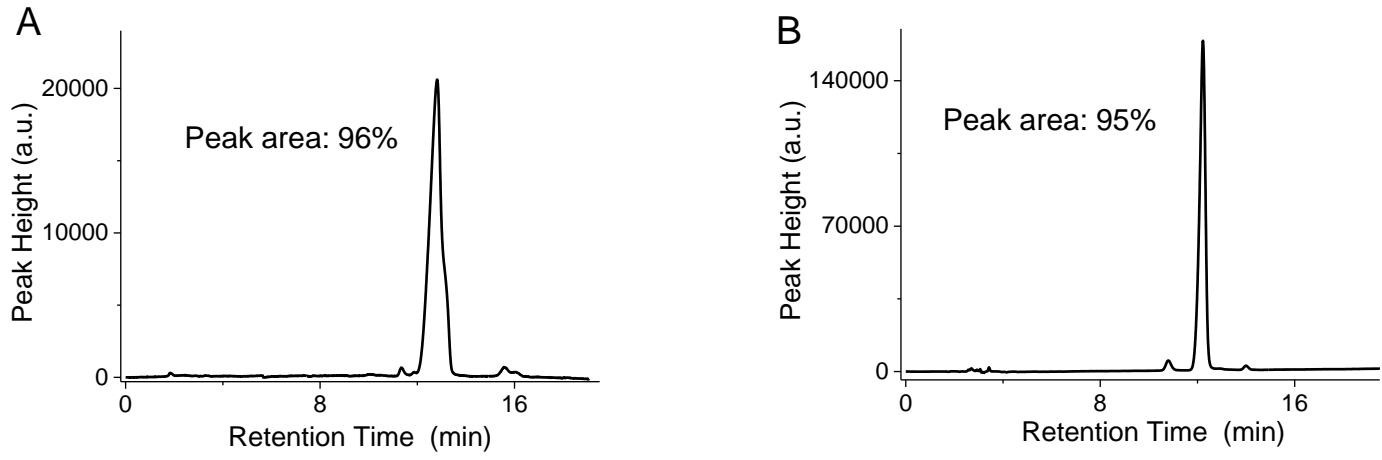

Figure S23. Chromatograms of different compounds monitored at $254 \mathrm{~nm}$. (A) FM1210. Eluents were $\mathrm{MeOH} / \mathrm{H}_{2} \mathrm{O}$ (v/v): from 8:2 to 8.75:1.25 in $20 \mathrm{~min}$; total flow rate, $1 \mathrm{~mL} / \mathrm{min}$. Retention time of FM1210 was $12.8 \mathrm{~min}$. (B) CF1065. Eluents were $\mathrm{MeOH} / \mathrm{H}_{2} \mathrm{O}(\mathrm{v} / \mathrm{v})$ : from 8:2 to $9: 1$ in $20 \mathrm{~min}$; total flow rate, $1 \mathrm{~mL} / \mathrm{min}$. Retention time of CF1065 was 12.2 min. Note: $\mathrm{H}_{2} \mathrm{O}$ containing $0.1 \%$ (v/v) TFA. The purity of FM1210 and CF1065 is $\geq 95 \%$. 


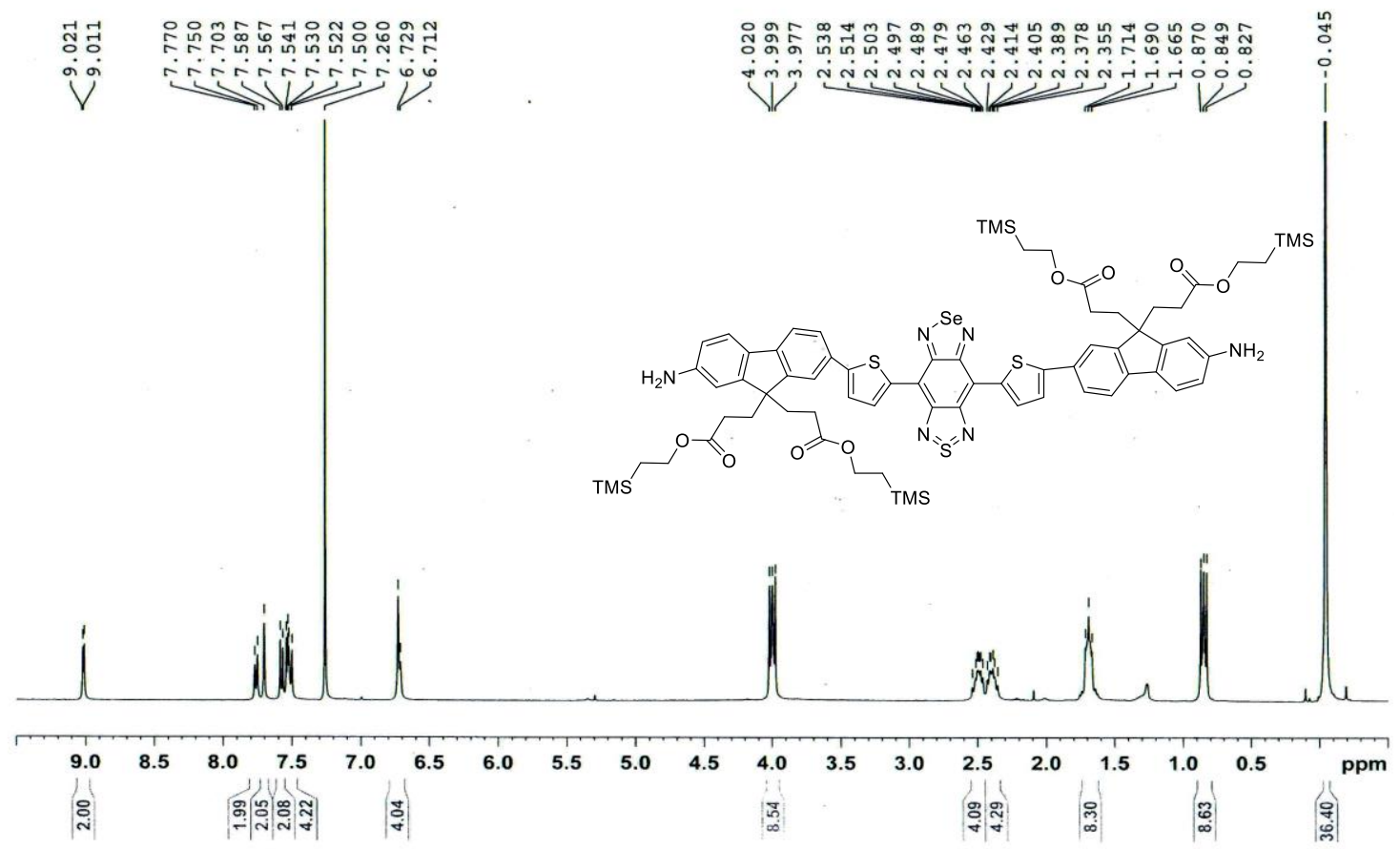

Figure S24. ${ }^{1} \mathrm{H}$ NMR spectrum of compound $3\left(400 \mathrm{MHz}, 298 \mathrm{~K}, \mathrm{CDCl}_{3}\right)$.

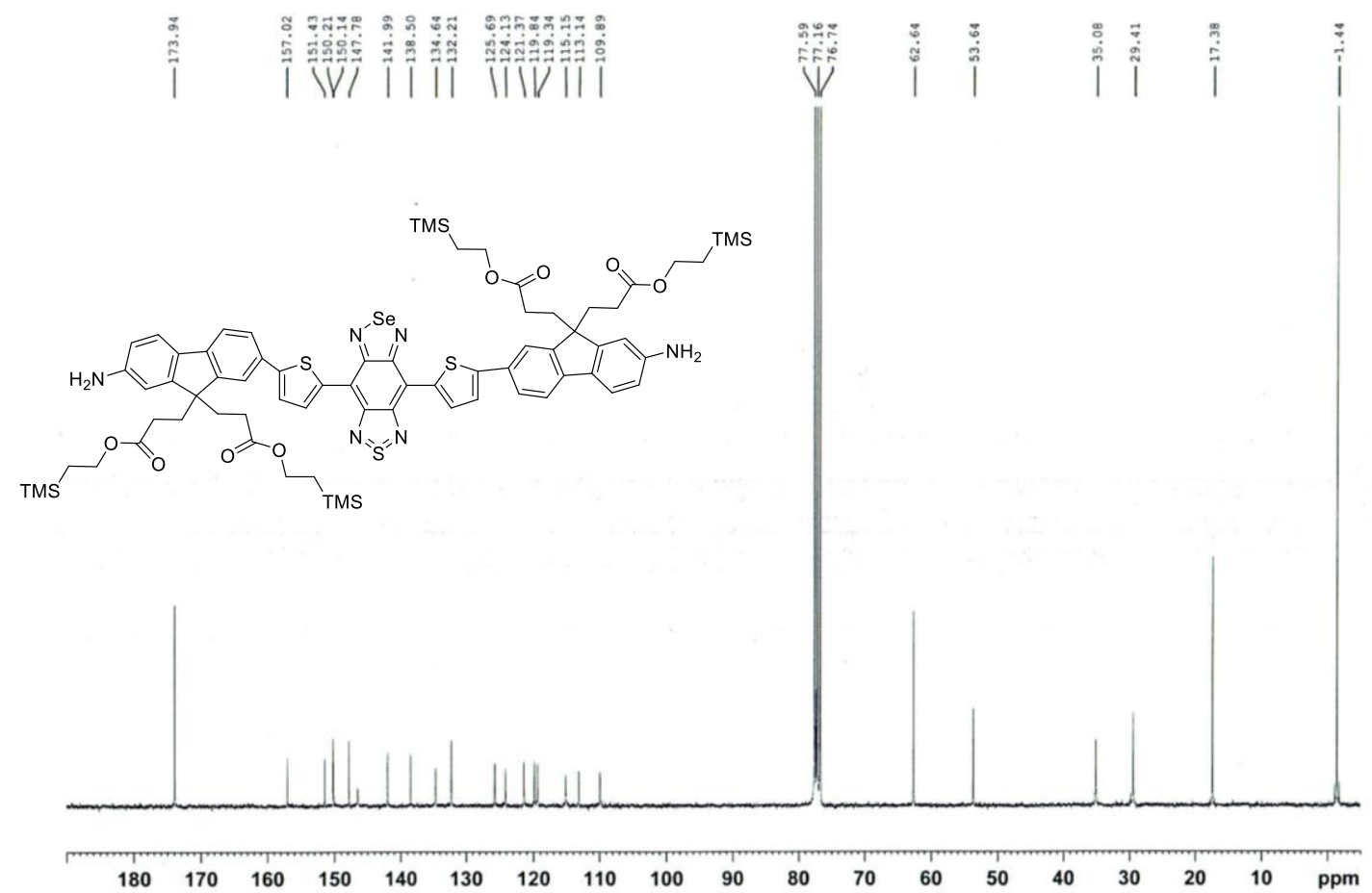

Figure S25. ${ }^{13} \mathrm{C}$ NMR spectrum of compound $3\left(75 \mathrm{MHz}, 298 \mathrm{~K}, \mathrm{CDCl}_{3}\right)$. 


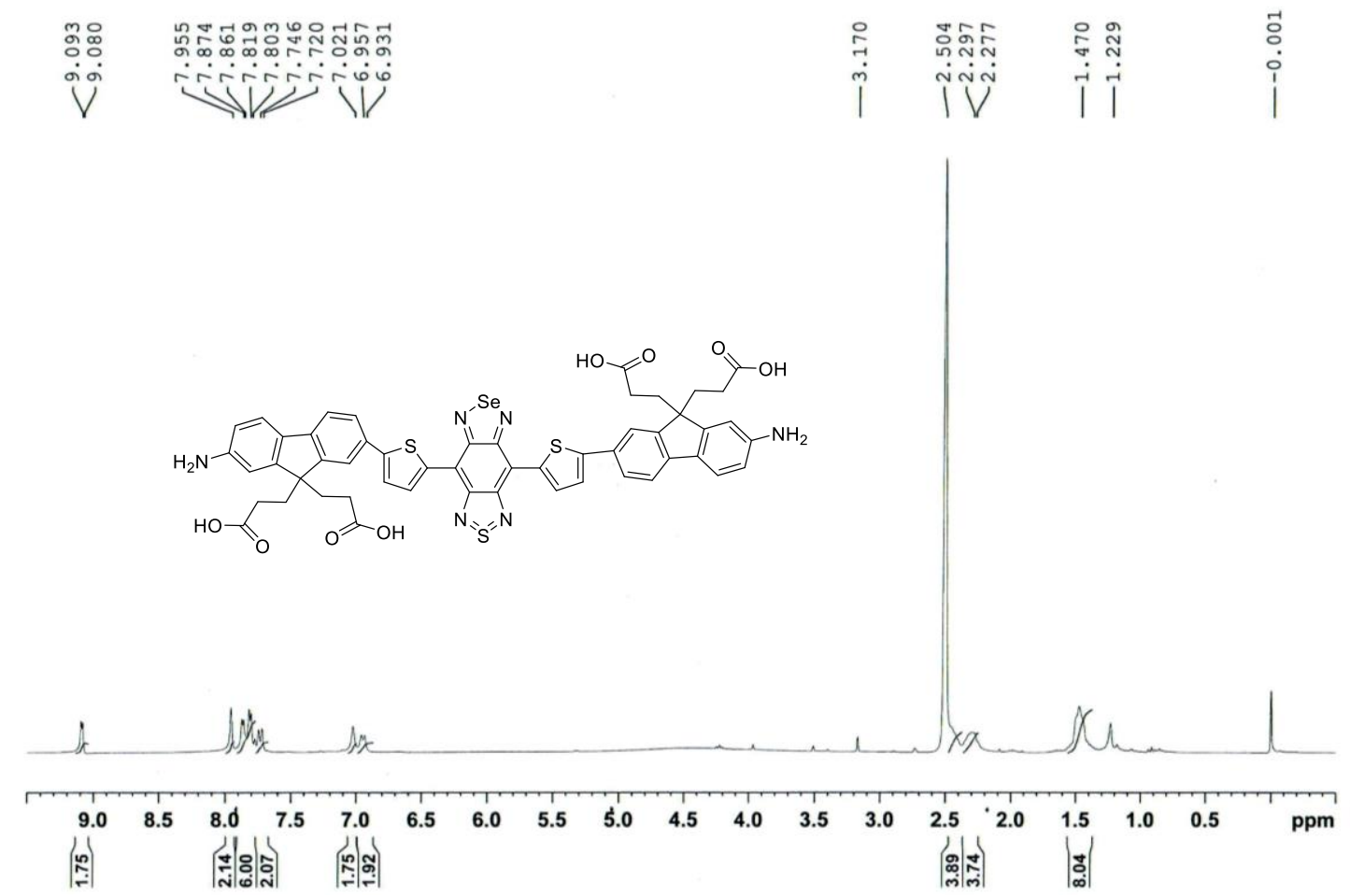

Figure S26. ${ }^{1} \mathrm{H}$ NMR spectrum of FM1210 (300 MHz, 298K, DMSO-d 6 ).
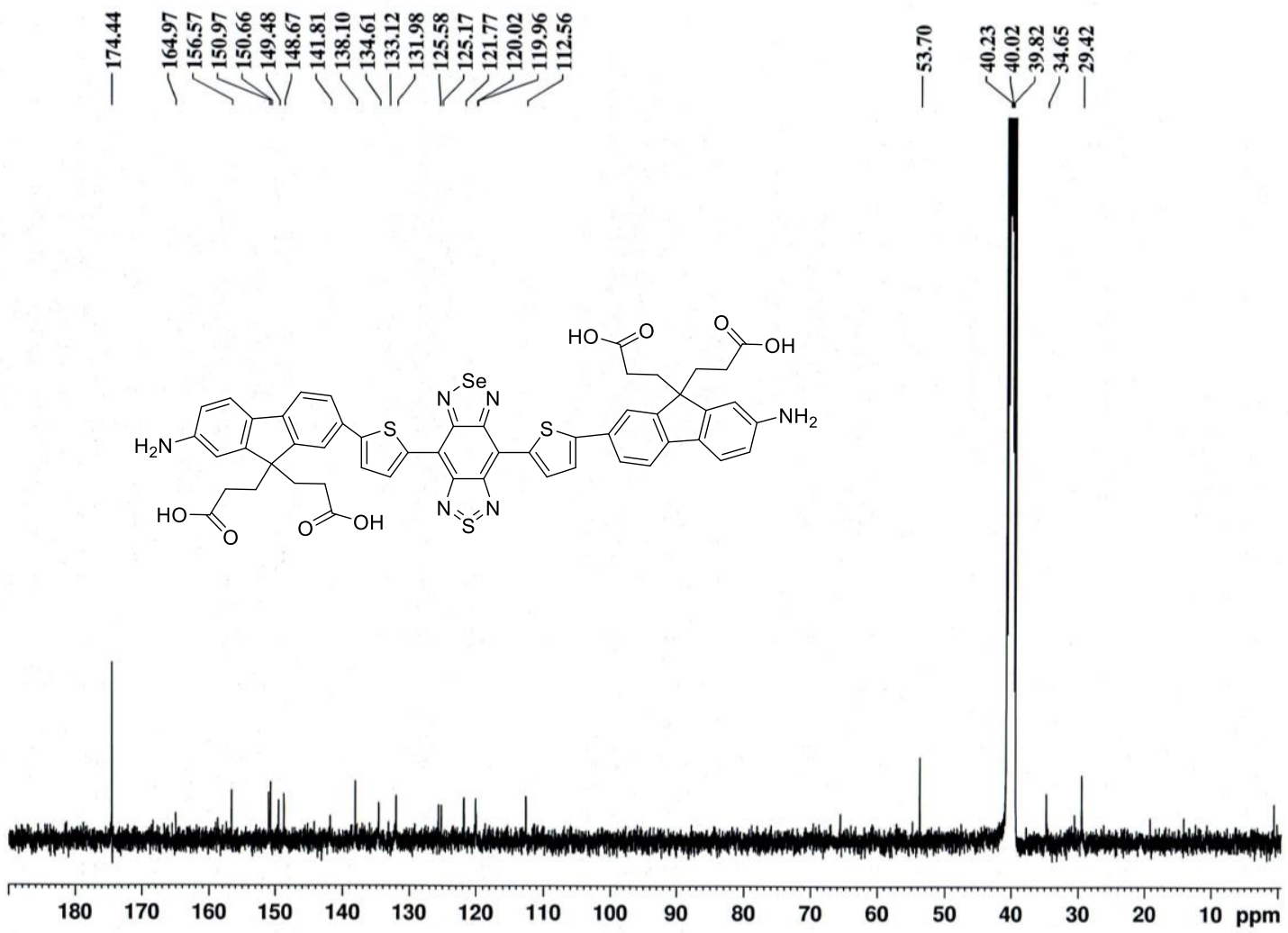

Figure S27. ${ }^{13} \mathrm{C}$ NMR spectrum of FM1210 (100 MHz, 298K, DMSO-d 6 ). 


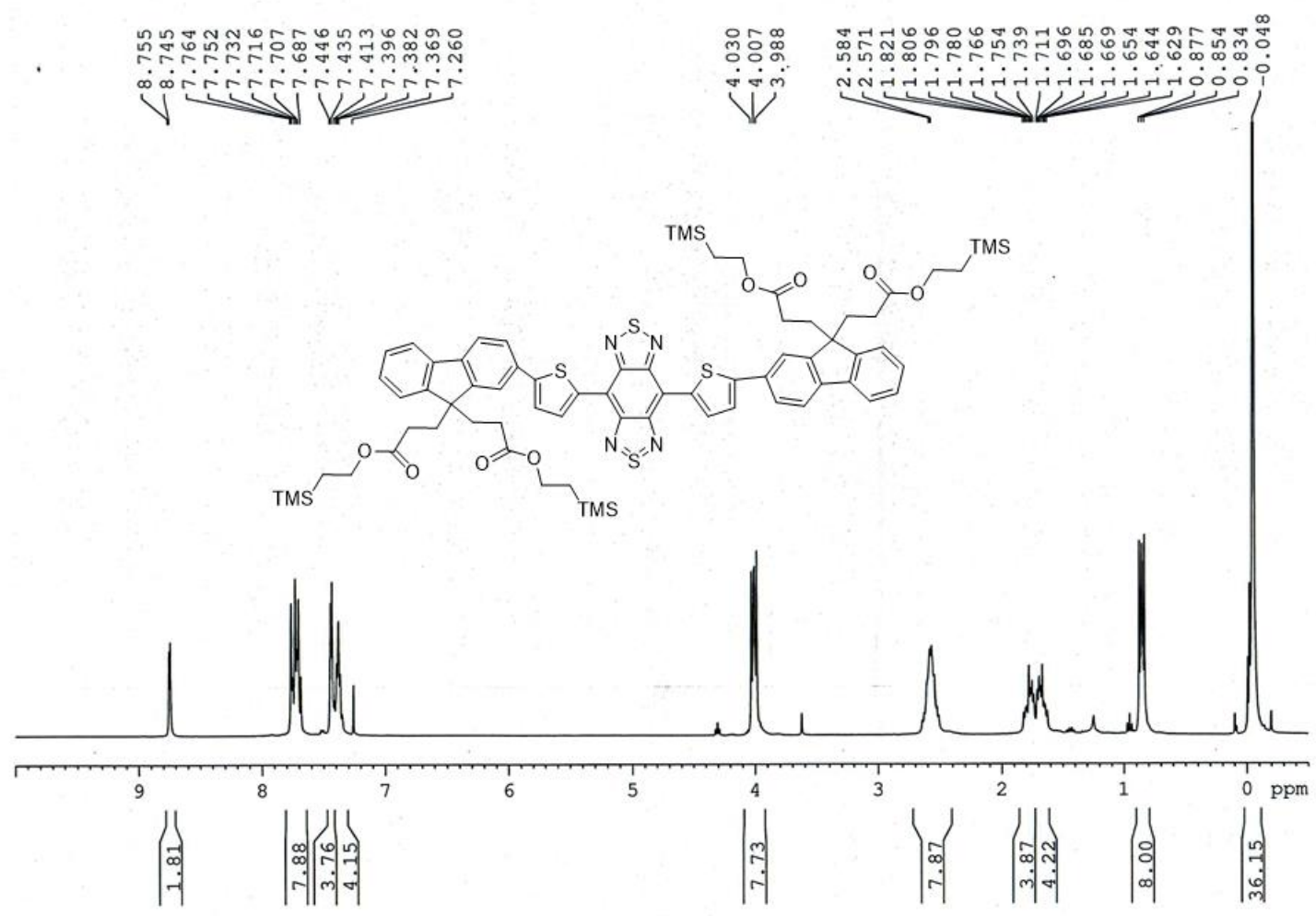

Figure S28. ${ }^{1} \mathrm{H}$ NMR spectrum of compound $8\left(400 \mathrm{MHz}, 298 \mathrm{~K}, \mathrm{CDCl}_{3}\right)$.
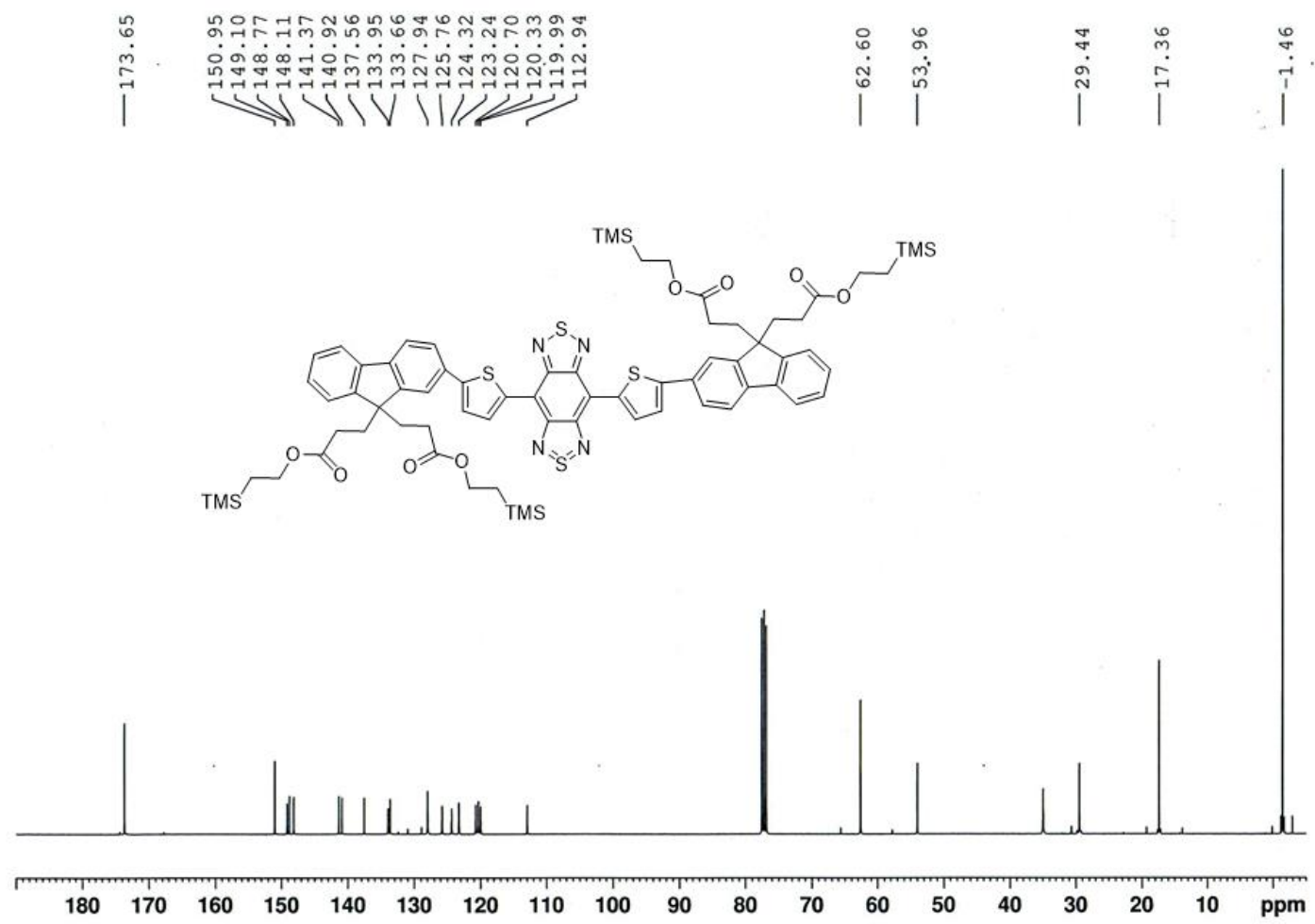

Figure S29. ${ }^{13} \mathrm{C}$ NMR spectrum of compound $8\left(100 \mathrm{MHz}, 298 \mathrm{~K}, \mathrm{CDCl}_{3}\right)$. 

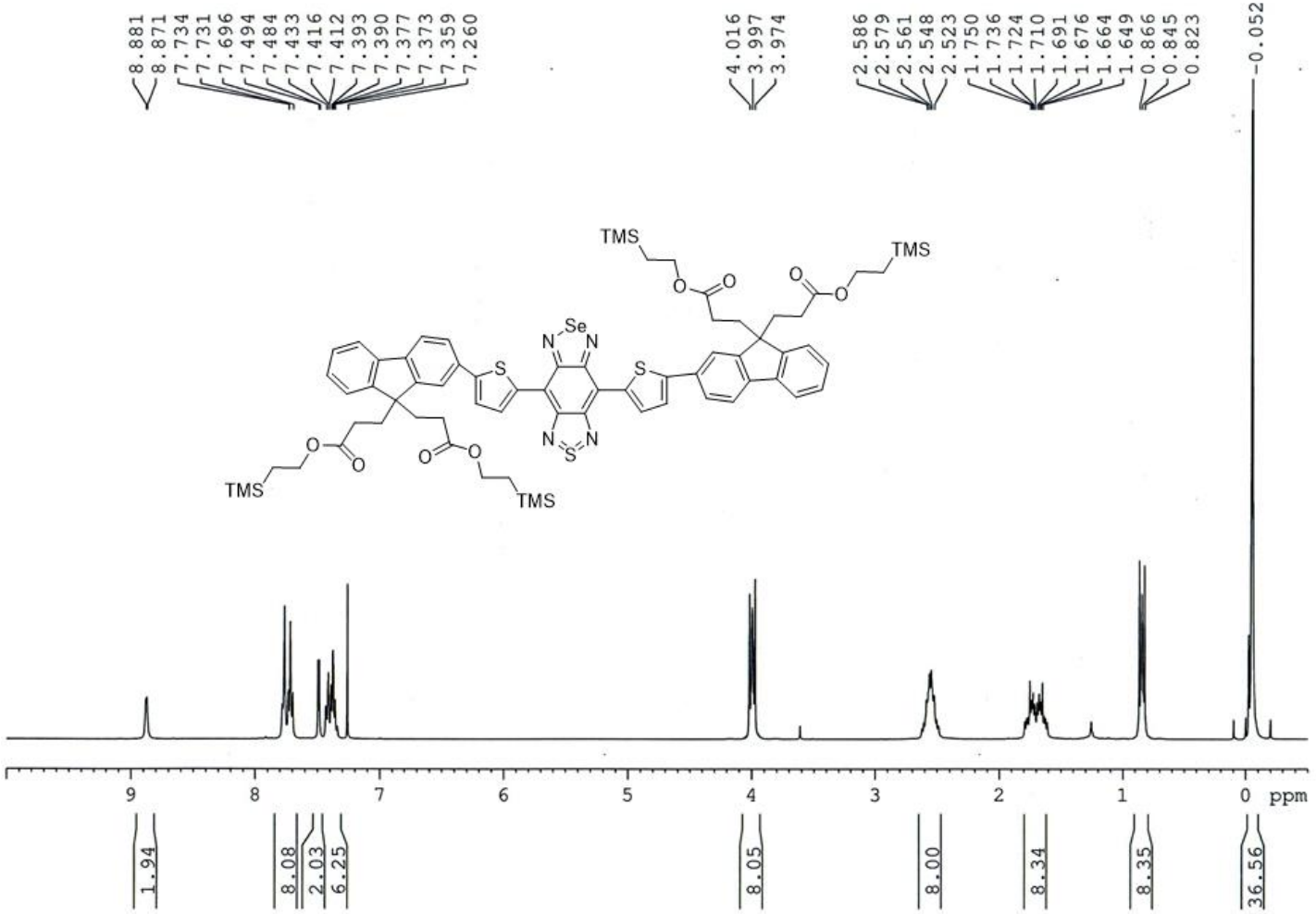

Figure S30. ${ }^{1} \mathrm{H}$ NMR spectrum of compound $9\left(400 \mathrm{MHz}, 298 \mathrm{~K}, \mathrm{CDCl}_{3}\right)$.

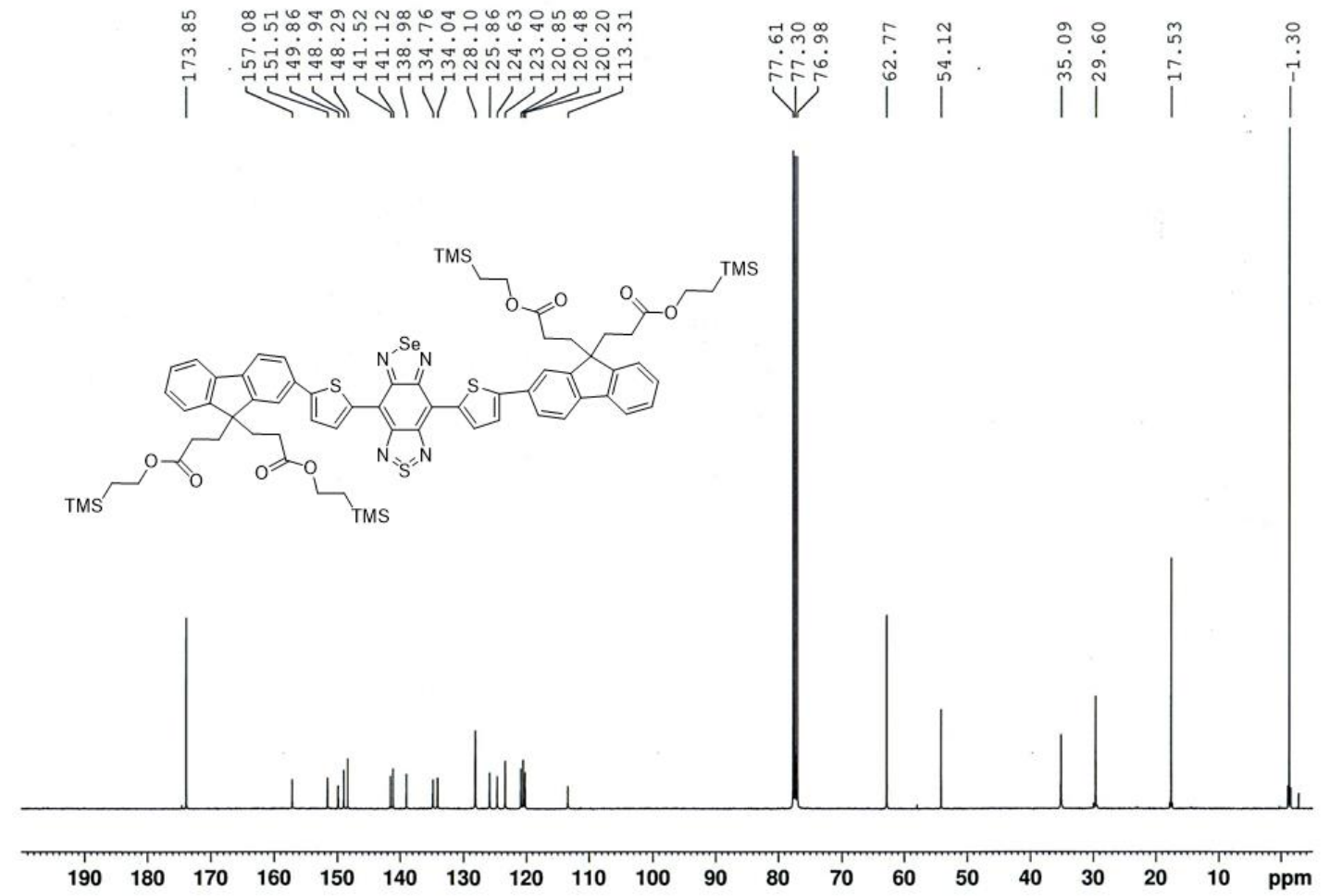

Figure S31. ${ }^{13} \mathrm{C}$ NMR spectrum of compound $9\left(100 \mathrm{MHz}, 298 \mathrm{~K}, \mathrm{CDCl}_{3}\right)$. 


\section{References}

(1) Sun Y.; Ding M.; Zeng X.; Xiao Y.; Wu H.; Zhou H.; Ding B.; Qu C.; Cheng Z.; Hong X. Novel bright-emission small-molecule NIR-II fluorophores for in vivo tumor imaging and image-guided surgery. Chem. Sci. 2017, 8 (5), 3489-3493.

(2) Karton-Lifshina N.; Segalb E.; Omerb L.; Portnoya M.; SatchiFainarob R.; Shabat D. A unique paradigm for a Turn-ON near-infrared cyanine-based probe: noninvasive intravital optical imaging of hydrogen peroxide. J. Am. Chem. Soc. 2011, 133 (28), 10960-10965.

(3) Semonin O. E.; Johnson J. C.; Luther J. M.; Midgett A. G.; Nozik A. J.; Beard M. C. Absolute photoluminescence quantum yields of IR-26 dye, PbS, and PbSe quantum dots. J. Phys. Chem. Lett. 2010, 1 (16), 2445-2450.

(4) Wan Q.; Chen S.; Shi W.; Li L.; Ma H. Lysosomal pH rise during heat shock monitored by a lysosome-targeting near-infrared ratiometric fluorescent probe. Angew. Chem. Int. Ed. 2014, 53 (41), 10916-10920.

(5) Antaris A. L.; Chen H.; Cheng K.; Sun Y.; Hong G.; Qu C.; Diao S.; Deng Z.; Hu X.; Zhang B.; Zhang X.; Yaghi O. K. Alamparambil Z. R., Hong X., Cheng Z., Dai H. A small-molecule dye for NIR-II imaging. Nat. Mater. 2016, 15 (2), 235-242.

(6) Sun Y.; Ding F.; Zhou Z.; Li C.; Pu M.; Xu Y.; Zhan Y.; Lue X.; Li H.; Yang G.; Sun Y.; Stang P. J. Rhomboidal Pt (II) metallacycle-based NIR-II theranostic nanoprobe for tumor diagnosis and image-guided therapy. Proc. Natl. Acad. Sci. USA 2019, 116 (6), 1968-1973.

(7) Zhu S.; Herraiz S.; Yue J.; Zhang M.; Wan H.; Yang Q.; Ma Z.; Wang Y.; Hsueh A. J.; Dai H. 3D NIR-II molecular imaging distinguishes targeted organs with high-performance NIR-II bioconjugates. Adv. Mater. 2018, 30 (13), 1705799.

(8) Zhang R.; Wang Z.; Xu L.; Xu Y.; Lin Y.; Zhang Y.; Sun Y.; Yang G. Anal. Chem. 2019, 91, 12476-12483.

(9) Yang Q.; Hu Z.; Zhu S.; Ma R.; Ma H.; Ma Z.; Wan H.; Zhu T.; Jiang Z.; Liu W.; Jiao L.; Sun H.; Liang Y.; Dai H. Donor engineering for NIR-II molecular fluorophores with enhanced fluorescent performance. J. Am. Chem. Soc. 2018, 140 (5), 1715-1724. 